\title{
STUDI KARAKTERISTIK GERUSAN LOKAL PADA BEBERAPA TIPE PILAR JEMBATAN
}

\section{STUDY OF LOCAL SCOURING CHARACTERISTICS SURROUNDINGS SEVERAL BRIDGE PILARS FORMS}

\author{
Sarwono \\ Pusat Litbang Sumber Daya Air \\ Jl. Solo-Kartasura KM 7 Solo 57162, Indonesia \\ E-mail: sarwono_bs@yahoo.go.id
}

Diterima: 24 Desember 2015; Direvisi: Januari 2016; Disetujui: 30 Maret 2016

\begin{abstract}
ABSTRAK
Gerusan lokal yang terbentuk di sekitar bentuk pilar jembatan mempunyai karakter yang berbeda dan beberapa bentuk pilar jembatan dianggap optimum apabila dilengkapi data: debit, kemiringan dasar sungai, material dasar, dan arah aliran yang sama. Tujuan penelitian ini adalah untuk mencari jenis pilar yang akan menghasilkan gerusan lokal yang paling dangkal (kecil). Alat yang digunakan adalah flume dengan panjang 10,00 $\mathrm{m}$, lebar 0,40 $\mathrm{m}$ dan tinggi 0,40 $\mathrm{m}$. Bentuk pilar yang diteliti adalah dua tiang silinder, tiang pancang dan dinding penuh. Kemiringan dasar sungai (i) dengan tiga variasi: 0,006, 0,0125 dan 0,020. Debit aliran yang digunakan ada lima variasi: $5,37 \mathrm{~m}^{3} / \mathrm{s}, 8,94 \mathrm{~m}^{3} / \mathrm{s}, 12,52 \mathrm{~m}^{3} / \mathrm{s}, 14,31 \mathrm{~m}^{3} / \mathrm{s}, 17,89 \mathrm{~m}^{3} / \mathrm{s}$. Material dasar sungai yang digunakan pasir ada tiga macam dengan nilai $d_{50}: 0,60 \mathrm{~mm}, 0,80 \mathrm{~mm}$ dan 1,00 mm. Metode penelitian meliputi: survei lapangan, pengujian model fisik 2 dimensi dengan skala 1:20. Hasil studi menunjukkan, untuk setiap bentuk pilar mempunyai karakter yang berbeda, gerusan terdalam pada titik samping pilar, pada awal menit pertama sampai menit ke 20 gerusan mendadak dalam dan bentuk dasar sungai di sekitar pilar naik turun tidak teratur. Pada menit ke 20 sampai akhir pengaliran, penurunan gerusan hampir linier dan garis gerusan merata. Secara umum pilar yang bentuk tiang pancang mempunyai gerusan terdangkal dibanding bentuk pilar lainnya, jadi bentuk pilar yang optimum adalah pilar bentuk tiang pancang.
\end{abstract}

Kata Kunci: Gerusan lokal, karakter gerusan, bentuk pilar jembatan, uji model fisik, flume

\begin{abstract}
The local scouring characteristic suroundings several bridge pillars forms have a different characteristics, some forms of pillars of the bridge are considered optimum when equipped with the data: discharge, slope of riverbed, material, and on the same flow direction, that will produce the most shallow scouring. The objective of this study is to find the form of pillars that will generate the most superficial scouring. The study is conducted at the Laboratory of River in Surakarta. The used flume has length of $10.00 \mathrm{~m}$, width $0.40 \mathrm{~m}$ and height of $0.40 \mathrm{~m}$. The forms of pillar studied are two cylindrical pillars, sheet pile and full walls pillar. The slope of the riverbed (i) are varied, there are three: 0.006, 0.0125 and 0.020 . The flow discharge rate there are five variations: $5,37 \mathrm{~m}^{3} / \mathrm{s}, 8,94 \mathrm{~m}^{3} / \mathrm{s}, 12,52 \mathrm{~m}^{3} / \mathrm{s}, 14,31 \mathrm{~m}^{3} / \mathrm{s}, 17,89 \mathrm{~m}^{3} / \mathrm{s}$. Land was used at material for river bed, and, there are three kinds of value $D_{50}: 0.60 \mathrm{~mm}, 0.80 \mathrm{~mm}$ and $1.00 \mathrm{~mm}$. The research method includes: a field survey, two dimension physical model test with 1:20 scale. The results showed for each pillar shapes have different characters. The deepest scouring suroundings the pillar beside the point, at the beginning of the first minute to the $20^{\text {th }}$ minute in a sudden deep scour the riverbed and form of river bed suroundings are the pillars up and down irregularly. In the $20^{\text {th }}$ minute until the end of the stream scouring decreased almost linearly lines are horizontzl. In general the pile type pillars was found to cause the minimum scouring than other pillar shapes.
\end{abstract}

Keywords: Local scouring, scouring of characteristics, forms of pillars bridge, physical model test, flume 


\section{PENDAHULUAN}

Gerusan lokal adalah proses alamiah yang terjadi di sungai akibat pengaruh morfologi sungai atau adanya bangunan yang menghalangi aliran, misalnya krib sungai, pangkal pilar jembatan dan lain-lain. Adanya bangunan tersebut bisa menyebabkan perubahan karakteristik aliran seperti pola aliran berubah menjadi aliran spiral atau turbulensi, perubahan kecepatan aliran, sehingga menimbulkan perubahan angkutan sedimen dan mengakibatkan gerusan lokal. Yuwono Sosrodarsono dan Kazuno Nakazawa (1981) mengemukakan bahwa kerusakan pada pilar jembatan akibat banjir sebagian besar disebabkan oleh arus sehingga terjadi pengurangan luas penampang sungai dengan adanya sejumlah tiangtiang (terutama pada jembatan kayu) pada aliran sungai dan hampir semua kerusakan pada jembatan disebabkan oleh perubahan dasar sungai atau penggerusan lokal (local scouring). Secara kenyataan di lapangan, gerusan yang terjadi pada pilar jembatan adalah merupakan gerusan total (total scour), yaitu kombinasi antara gerusan lokal (local scour) dan gerusan umum (general scour). Bisa juga kombinasi antara gerusan lokal, gerusan umum dan gerusan terlokalisir (localized scour / constriction scour). Gerusan umum yang terjadi melintang sungai di sepanjang saluran yang menyebabkan degradasi dasar disebabkan oleh energi dari aliran air, sedang gerusan lokal yang terjadi di sekitar pilar jembatan disebabkan oleh sistem pusaran air (vortex system) karena adanya gangguan pola aliran akibat rintangan, dan gerusan terlokalisir terjadi karena adanya penyempitan penampang sungai oleh adanya infrastruktur sungai.

Fenomena ini bisa menyebabkan erosi dan degradasi di sekitar bukaan jalan air (water way openning) suatu jembatan. Degradasi ini berlangsung secara terus menerus hingga dicapai keseimbangan antara suplai dan angkutan sedimen yang saling memperbaiki. Apabila suplai sedimen dari hulu berkurang atau jumlah angkutan sedimen lebih besar daripada suplai sedimen, maka bisa menyebabkan terjadinya kesenjangan yang begitu menyolok antara degradasi dan agradasi di lokasi dasar saluran pada jembatan. Sehingga lubang gerusan (scour hole) pada pilar jembatan akan lebih dalam bila tidak terdapat atau kurangnya suplai sedimen. Demikian juga apabila tidak terdapat bangunan pengendali gerusan di sekitar abutmen ataupun pilar, maka dalamnya gerusan tidak bisa direduksi, sehingga kedalaman gerusan bisa mencapai maksimum. Hal ini bisa menyebabkan rusaknya pilar jembatan, seperti yang pernah terjadi pada kasus jembatan
Srandakan sungai Progo di Propinsi Daerah Istimewa Yogyakarta tahun 2000 silam.

Berdasarkan permasalahan $\mathrm{di}$ atas Balai Sungai mencoba melakukan penelitian untuk mencari kedalaman gerusan di pilar jembatan (gerusan lokal) dengan menggunakan 3 (tiga) jenis pilar yang berbeda.

Dari hasil studi dapat diperoleh gambaran bahwa gerusan lokal dapat menyebabkan terjadinya arus pusar. Dari arus pusar ini akan membawa butiran material dasar menjauh dari asalnya dan akan terisi dari hulunya. Bila debit sedimen yang keluar lebih besar dari yang masuk maka akan tertipe lubang akibat penggerusan.

Perencana sebuah jembatan dalam memilih atau menentukan tipe pilar yang tepat, memerlukan data studi gerusan lokal pada masingmasing tipe pilar, dengan tujuan agar bisa diperoleh jenis pilar yang tepat dan memberikan dampak gerusan terkecil. Hasil akhir yang diharapkan adalah terpilihnya tipe pilar yang tepat sesuai dengan kondisi sungai setempat.

\section{KAJIAN PUSTAKA}

\section{Persamaan Gerusan Untuk Aliran Beraturan}

Breuser dan Raudkivi (1991), menyebutkan bahwa parameter yang mempengaruhi dalamnya gerusan akibat bangunan sungai adalah karakteristik zat cair, material dasar sungai, aliran dalam saluran, dan tipe pilar jembatan. Dalamnya gerusan pada dasar sungai di sekitar pilar jembatan merupakan akibat adanya aliran sungai yang mengkikis lapisan tanah dasar dapat dihitung kedalamannya. Pada kondisi clear-water, dalamnya gerusan dapat dihitung dengan persamaan sebagai berikut:

$\mathrm{Y}_{\mathrm{se}}: 2,3 \mathrm{~K}_{\mathrm{a}} \mathrm{K}_{\mathrm{s}} \mathrm{K}_{\alpha} \mathrm{K}_{\mathrm{s}} \mathrm{K}_{\mathrm{d}}(\mathrm{m})$

Dimana:

$\mathrm{Y}_{\mathrm{se}}$ : kedalaman gerusan seimbang $(\mathrm{m})$

$\mathrm{K}_{\mathrm{a}}$ : faktor posisi pilar

$\mathrm{K}_{\mathrm{s}}$ : faktor tipe pilar

$\mathrm{K}_{\alpha}$ : sudut dalam alir

$\mathrm{K}_{\mathrm{s}}$ :faktor ukuran pilar

\section{$K_{d}$ faktor ketinggian pilar}

Melville dan Satherland (1988) menjelaskan bahwa kedalaman gerusan lokal $Y_{s e}$ dapat ditulis dengan persamaan:

$\mathrm{Y}_{\mathrm{se}}: \mathrm{K}_{1} \mathrm{~K}_{\partial} \mathrm{K}_{\mathrm{s}} \mathrm{K}_{\alpha} \mathrm{K}_{\mathrm{s}} \mathrm{K}_{\mathrm{d}}(\mathrm{m})$

Dimana:

$\mathrm{Y}_{\mathrm{se}}$ : kedalaman gerusan seimbang $(\mathrm{m})$

$\mathrm{K}_{1}$ : faktor intensitas aliran

$\mathrm{K}_{\partial}$ : fungsi dari standar deviasi geometrik ukuran partikel 
$\mathrm{K}_{\mathrm{s}}$ : faktor tipe pilar

$\mathrm{K}_{\alpha}$ : faktor posisi pilar [0,78 (y0/b) 0,225]

$\mathrm{K}_{\mathrm{s}}$ : faktor ukuran pilar

$\mathrm{K}_{\mathrm{d}}$ : faktor ketinggian pilar

Keterangan:

$\mathrm{K}_{1}: 2,4(\mathrm{U} / \mathrm{Uc}$ jika $(\mathrm{U} / \mathrm{Uc})<1$

$\mathrm{K}_{1}: 2,4$ jika (U/Uc) $>1$

Besaran nilai semua faktor tergantung padatipe pilar. White (1940) dalam Brueusers Delft (1981 - 1982),memberi pernyataan mengenai keseimbangan partikel (butiran) di dasar sungai. Adapun pernyataannya adalah bahwa gaya yang mempengaruhi kekuatan (disturbing force) yang merupakan resultante gaya seret dan gaya angkat akan sebanding dengan tegangan geser dasar sungai dan luas permukaan butiran $\left(D^{2}\right)$, dan gaya tahan gravitasi sebanding dengan berat partikel di dalam air: $\left(\rho_{s}-\rho_{w}\right) \cdot g . D^{3}$. Kemudian, butiran akan diam jika: $\tau_{\mathrm{o}}<$ c. $\left(\rho_{\mathrm{s}}-\rho_{\mathrm{w}}\right)$. g. $\mathrm{D}$

Dimana:

$$
\begin{array}{lll}
\tau_{\mathrm{o}} & : & \rho_{\mathrm{w}} . \mathrm{g} . \mathrm{h} . \mathrm{I} \text { : tegangan geser }\left(\mathrm{N} / \mathrm{m}^{2}\right) \\
\rho_{\mathrm{s}} & : \text { kerapatan sedimen }\left(\mathrm{kg} / \mathrm{m}^{3}\right) \\
\rho_{\mathrm{w}} & : \text { kerapatan air }\left(\mathrm{kg} / \mathrm{m}^{3}\right) \\
\mathrm{g} & : \text { percepatan gravitasi }\left(\mathrm{m} / \mathrm{s}^{2}\right) \\
\mathrm{D} & : \text { diameter butiran }(\mathrm{m}) \\
\mathrm{h} & : \text { kedalaman air }(\mathrm{m}) \\
\mathrm{i} & : \text { kemiringan dasar saluran }(\mathrm{m} / \mathrm{m}) \\
\mathrm{c} & : \text { konstante. }
\end{array}
$$

\section{Gerusan}

Laursen (1952) dalam Hanwar mendefinisikan gerusan sebagai pembesaran dari suatu aliran yang disertai pemindahan material melalui aksi gerakan fluida. Gerusan lokal (local scouring) terjadi pada suatu kecepatan aliran di mana sedimen terangkut lebih besar dari sedimen yang disuplai. Angkutan sedimen bertambah dengan meningkatnya tegangan geser sedimen, gerusan terjadi ketika perubahan kondisi aliran menyebabkan peningkatan tegangan geser dasar (Rita. M, 2010)

\section{Mekanisme Gerusan}

Menurut Miller, jika struktur ditempatkan pada suatu arus air, aliran air di sekitar struktur tersebut akan berubah, dan gradien kecepatan vertikal (vertical velocity gradient)dari aliran akan berubah menjadi gradien tekanan (pressure gradient)pada ujung permukaan struktur tersebut. Gradien tekanan (pressure gradient) ini merupakan hasil dari aliran bawah yang membentur bed.Pada dasar struktur, aliran bawah ini membentuk pusaran yang pada akhirnya menyapu sekeliling dan bagian bawah struktur dengan memenuhi seluruh aliran. Hal ini dinamakan pusaran tapal kuda (horseshoe vortex), karena dilihat dari atas tipe pusaran ini mirip tapal kuda. Pada permukaan air, interaksi aliran dan struktur membentuk busur ombak (bow wave) yang disebut sebagai gulungan permukaan (surface roller).

\section{Persiapan uji model fisik}

\section{Pemeriksaan Material Dasar}

Sebelum melakukan pengujian, langkah awal yang perlu dilakukan adalah menentukan bahan dasar material yang digunakan untuk tes gerusan. Material di sekitar pilar dilakukan tes Laboratorium Tanah untuk mengetahui distribusi butiran dan berat jenisnya. Bahan dasar yang digunakan untuk tes gerusan berupa pasir pasang sebagai tiruan untuk menirukan material dasar sungai di lapangan.

Penyelidikan gerusan di sekitar pilar ini dilakukan ada 3 jenis material bahan dasar yaitu material halus ( $\left.D_{50}: 0,6 \mathrm{~mm}\right)$, material medium ( $D_{50}: 0,80 \mathrm{~mm}$ ) dan material kasar $\left(D_{50}: 1,00 \mathrm{~mm}\right)$ rapat masa rata-rata $\left(\rho_{\mathrm{s}}\right)$ : $2650 \mathrm{~kg} / \mathrm{m}^{3}$.

\section{Analisis Kedalaman Aliran}

Persiapan yang harus dilakuan sebelum melakukan percobaan pengaliran harus diketahui kedalaman air untuk setiap debit aliran. Kedalaman air (h) dihitung dengan rumus sederhana Chow (1985).

$$
\begin{aligned}
& \mathrm{Q}=\mathrm{A} \times \mathrm{vQ}=\mathrm{A} \times \mathrm{V} \\
& \mathrm{A}=\mathrm{h} \times \mathrm{b} \\
& V=\frac{1}{n} x(R)^{\frac{2}{3}} x(i)^{\frac{1}{2}}
\end{aligned}
$$

Dimana :

Q : debit aliran $\left(\mathrm{m}^{3} / \mathrm{s}\right)$

A : luas tampang basah $\left(\mathrm{m}^{2}\right)$

$\mathrm{h}$ : kedalaman air di flume $(\mathrm{m})$

b : lebar saluran $(0,40 \mathrm{~m})$

n : angka kekasaran manning sebagai berikut: material halus $\left(D_{50}: 0,6 \mathrm{~mm}\right): 0,020$. medium (D.50 : 0,80 mm) 0,022 dan material kasar (D.50: 1,00 mm) diambil angka kekasaran manning : 0,023.

$\mathrm{R}$ : jari-jari hidaulis (m) : A/P

$\mathrm{P}$ : keliling basah $(\mathrm{m})$

I : kemiringan dasar sungai diambil 3 variasi sebagai berikut: 0,006, 0,0125, dan 0,020, namun yang disajikan dalam tulisan ini hanya dibahas untuk 1 (satu) kemiringan dasar yaitu: I : $(0,006)$.

Analisis kedalaman air berdasarkan rumus di atas dapat dilihat pada Tabel 1. 
Tabel 1 Analisis kedalaman air (h) berdasarkan rumusan

\begin{tabular}{|c|c|c|c|}
\hline \multicolumn{4}{|c|}{ Butiran halus $\mathrm{Dm}: 0,60 \mathrm{~mm}$} \\
\hline No & Debit Aliran & Kemiringan & Kedalaman air \\
\hline & $\left(\mathrm{m}^{3} / \mathrm{s}\right)$ & Dasar Saluran (i) & (h) $(\mathrm{m})$ \\
\hline 1 & 5,37 & 0,006 & 0,56 \\
\hline 2 & 8,94 & 0,006 & 0,68 \\
\hline 3 & 12,52 & 0,006 & 0,80 \\
\hline 4 & 14,31 & 0,006 & 0,86 \\
\hline 5 & 17,89 & 0,006 & 0,98 \\
\hline 1 & 5,37 & 0,0125 & 0,40 \\
\hline 2 & 8,94 & 0,0125 & 0,48 \\
\hline 3 & 12,52 & 0,0125 & 0,56 \\
\hline 4 & 14,31 & 0,0125 & 0,60 \\
\hline 5 & 17,89 & 0,0125 & 0,68 \\
\hline 1 & 5,37 & 0,020 & 0,45 \\
\hline 2 & 8,94 & 0,020 & 0,53 \\
\hline 3 & 12,52 & 0,020 & 0,61 \\
\hline 4 & 14,31 & 0,020 & 0,65 \\
\hline 5 & 17,89 & 0,020 & 0,72 \\
\hline
\end{tabular}

3 Karakteristik Aliran

Sebelum dilakukan uji pengaliran, maka harus diketahui sifat-sifat hidrauliknya terlebih dahulu. Untuk mengetahui karakteristik aliran, perlu dilakukan analisis berdasarkan formulasi hidraulik. Parameter yang berpengaruh terhadap karakteristik aliran adalah:
1) Debit aliran (Q)
2) Kemiringan dasar saluran (i)
3) Kekentalan kinematik (v)
4) Kerapatan (density) air maupun bahan material dasar sungai $(\rho)$
5) Kedalaman air (h)
6) Kecepatan geser $\left(\mathrm{U}^{*}\right)$
7) Kecepatan aliran rata-rata ( $\bar{U})$
8) Percepatan gravitasi (g)

Bahan dasar material yang digunakan untuk studi gerusan ini terdapat tiga macam serbuk batu bara:

1) Material halus dengan diameter rata-rata $\left(D_{\mathrm{m} 50}\right): 0,60 \mathrm{~mm}$,

2) Material medium dengan diameter rata-rata $\left(D_{\mathrm{m}} 50\right): 0,80 \mathrm{~mm}$

3) Material kasar dengan diameter rata-rata $\left(D_{m}\right.$ 50) : 1,00 mm

Untuk menganalisis karakteristik hidraulik aliran (Chow, 1985) antara lain:
1) Angka Froude $:(F r)=\frac{U}{\sqrt{g h}}$

2) Angka Reynolds : $(\operatorname{Re})=\frac{U^{*} x D}{v}$

3) Kecepatan Geser : $\left(\mathbf{U}^{*}\right)=(\mathbf{g} \mathbf{x h} \mathbf{x i})^{\frac{1}{2}}$

4) Koefisien Chezy :

$$
\text { (C) }=18 \log 12 \times \frac{\mathrm{h}}{\mathrm{ks}}
$$

5) Kekasaran Dasar Sungai : (ks) $=\mathbf{D}_{\mathbf{m} 65}$

6) Kedalaman Air di Flume $: \mathrm{h}$

7) Tebal lapisan batas laminar: $(\delta)=11.6 \frac{\mathrm{U}}{\mathbf{U}^{*}}$

8) Kekentalan Kinematik Air untuk temperatur

(T) : $20^{0} \mathrm{C}: 1,01 \times 10^{-6} \mathrm{~m}^{2} / \mathrm{s}$

Ketentuan jenis aliran:

$\mathrm{FR}<1 \quad$ : Sub Kritis

FR : $1 \quad$ : Kritis

FR $>1$ : Super Kritis

$\operatorname{Re}<500 \quad$ : Laminer

Re : 500 :Transisi

$\operatorname{Re}>500$ : Turbulen

Ks $<0,3 \delta \quad:$ Hidraulik licin 
Ks $>0,3 \delta$ : Hidraulik kasar

4 Karakter Pergerakan Bahan Dasar Material di Alur Sungai

Bahan dasar material yang digunakan untuk studi terdiri atas tiga macam, yaitu pasir halus, medium untuk dan kasar.

Untuk mengetahui kondisi hidraulik pada masing-masing jenis butiran pada bagian dasar saluran, apakah termasuk hidraulik licin, transisi, kasar, dilakukan dengan cara dialiri debit tertentu maka perlu di analisis berdasarkan rumus keadaan hidraulik pada bagian dasar sungai sebagai berikut: Ks $<0,3 \delta$ higraulik licin.

Ks $>0,3 \delta$ hidraulik kasar.

Air yang mengalir pada permukaan sedimen menimbulkan gaya pada butiran, yang cenderung menggerakannya. Gaya yang menahan gaya yang ditimbulkan oleh air mengalir, berbeda-beda sesuai dengan ukuran butir dan distribusi ukuran sedimen. Untuk sedimen kasar misalnya (pasir dan krikil), gaya penahan gerakan disebabkan oleh berat partikel. Sedimen halus yang sedikit mengandung lumpur atau tanah liat atau keduanya, cenderung bersifat kohesip dan menahan gerakan dengan gaya kohesinya dari pada dengan gaya berat butir secara individu.

Dengan demikian dapat disimpulkan bahwa pada sekelompok sedimen atau butiran halus akan digerakan sebagai satu kesatuan, sedangkan pada sedimen kasar yang bersifat non kohesif digerakan sebagai butiran -butiran yang bebas.

Bila gaya hidraulik bekerja pada suatu butiran kasar, maka dengan penambahan gaya hidraulik sedikit, butiran akan mulai bergerak, hal ini dikatakan keadaan kritis, bila kondisi kritis tersebut mencapai suatu nilai atau besaran sebesar gaya geser dasar saluran, maka kecepatan rataratanya telah mencapai kondisi kritis. Pada kondisi semacam ini aliran mempunyai kemampuan untuk menggerakan butiran sedimen.

Karakteristik pergerakan bahan dasar material di alur sungai, akan ditentukan keseimbangan kritis. Keseimbangan kritis adalah batas pada saat akan mulai terjadi gerakan butiran. Suatu teori didasarkan pada pertimbangan bahwa gaya seret berkaitan dengan kecepatan aliran, dengan keseimbangan aliran, keseimbangan kritis dirumuskan sebagai berikut:

$\Psi \mathrm{cr}:\left(\mathrm{U}^{*} \mathrm{cr}\right)^{2} / \Delta, \mathrm{g}, \mathrm{D}$

Dimana:

$\Psi \mathrm{cr} \quad$ : gaya seret kritis ( -)

$\mathrm{U}^{*} \mathrm{cr}$ : kecepatan geser kritis (m/s)

D : diameter butiran (m)

$\Delta \quad$ : rapat massa relatif

$\Delta \quad:\left(\rho s-\rho_{\mathrm{w}}\right) / \rho_{\mathrm{w}}$

Sebagai ketentuan bahwa:

to : $\tau$ cr kondisi butiran akan bergerak

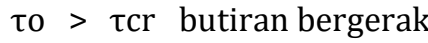

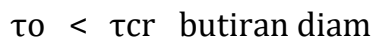

atau $\mathrm{U}^{*}: \mathrm{U}^{*} \mathrm{cr}$ kondisi butiran akan bergerak

$\mathrm{U}^{*}>\mathrm{U}^{*} \mathrm{cr}$ butiran bergerak

$\mathrm{U}^{*}<\mathrm{U}^{*} \mathrm{cr}$ butiran diam

\section{Analisis Hidraulik}

Analisis pergerakan butiran yang diformulasikan sesuai dengan sampel yang dipakai untuk penyelidikan di laboratorium adalah sebagai berikut:

Sebelum dilakukan studi gerusan lokal di laboratorium, parameter hidraulik dihitung berdasarkan formulasi yang berlaku pada angkutan sedimen. Analisis hidraulik yang dikaji terkait dengan angkutan sedimen antara lain, keadaan hidraulik dasar saluran, jenis aliran, dan tinjauan gerak sedimen. Sedangkan persiapan lain yang harus dilakuan sebelum melakukan percobaan pengaliran, yaitu dengan menguji material di sekitar pilar dilakukan tes Laboratorium Tanah untuk mengetahui distribusi butiran dan berat jenisnya. Bahan dasar yang digunakan untuk tes gerusan berupa pasir pasang sebagai tiruan untuk menirukan material dasar sungai dilapangan.

Data yang digunakan untuk memprediksi gerusan lokal di laboratorium padaTabel 2 .

Tabel 2 Skenario prediksi gerusan lokal

\begin{tabular}{lllll}
\hline $\begin{array}{l}\text { Debit aliran } \\
\left(\mathrm{m}^{3} / \mathrm{s}\right)\end{array}$ & $\begin{array}{l}\text { Kemiringan dasar } \\
\text { saluran (i) }\end{array}$ & $\begin{array}{l}\text { Diameter } \\
\text { bahan } \\
\text { saluran } \mathrm{d}_{50},\end{array}$ & $\begin{array}{c}\text { butiran } \\
\text { dasar }\end{array}$ & $\begin{array}{l}\text { Jenis } \\
\text { bentuk pilar }\end{array}$ \\
\hline 5,37 & 0,006 & 0,60 & Dua silinder \\
8,94 & 0,0125 & 0,80 & Tiang pancang \\
12,52 & 0,020 & 1,00 & Dinding penuh \\
14,31 & & & \\
17,89 & & & \\
\hline
\end{tabular}


Sebelum dilakukan pengaliran di model fisik flume, perlu diprediksi parameter hidraulik terutama untuk menentukan kedalaman air di saluran, kondisi hidraulik yang berdasarkan data dipakai untuk pengaliran. Hasil analisis hidraulik secara teoritsuntuk masing-masing kemiringan dasar saluran disajikan dalam Tabel 3, 4 dan 5.

Tabel 3 Keadaan hidraulik untuk kemiringan dasar saluran (i) : 0,006 dan diameter butiran rata-rata: 0,6 mm $(0,0006 \mathrm{~m})$

\begin{tabular}{|c|c|c|c|c|c|c|c|c|c|c|c|c|}
\hline $\begin{array}{l}Q \\
\left(\mathrm{~m}^{3} / \mathrm{s}\right)\end{array}$ & $\begin{array}{l}\mathrm{h} \\
\text { (m) }\end{array}$ & $\begin{array}{l}R \\
\text { (m) }\end{array}$ & $\begin{array}{l}U^{*} \\
(\mathrm{~m} / \mathrm{s})\end{array}$ & $\begin{array}{l}V \\
(\mathrm{~m} / \mathrm{s})\end{array}$ & $\begin{array}{l}\text { Ks } \\
\text { (m) }\end{array}$ & $\left(\mathrm{m}^{2} / \mathrm{s}\right)$ & $\begin{array}{l}0,3 \delta \\
\left(\mathrm{m}^{2} / \mathrm{s}\right) \\
\end{array}$ & $\begin{array}{l}6, \partial \\
\left(\mathrm{m}^{2} / \mathrm{s}\right)\end{array}$ & $\begin{array}{l}\text { U*cr } \\
\text { Grafik } \\
\text { Shields }\end{array}$ & FR & $\operatorname{Re}$ & $\begin{array}{l}\text { Kondisi hidraulik } \\
\text { dan dasar sungai }\end{array}$ \\
\hline 5.37 & 0.56 & 0.49 & 170 & 41 & 0.0006 & E-06 & $2 \mathrm{E}-06$ & -05 & 0.018 & 1.029 & 1446.69 & $\begin{array}{l}\text { Kasar, bergerak, Super } \\
\text { kritik, Turbulen } \\
\text { Kasar, bergerak, Super }\end{array}$ \\
\hline 8.94 & 0.68 & 0.58 & 0.185 & 2.70 & 0.0006 & $6 \mathrm{E}-06$ & $2 \mathrm{E}-06$ & $4 \mathrm{E}-05$ & 0.018 & 1.044 & 1618.34 & $\begin{array}{l}\text { kritik, Turbulen } \\
\text { Kasar, bergerak, Super }\end{array}$ \\
\hline 12.52 & 0.80 & 0.67 & 0.198 & 2.96 & 0.0006 & $6 \mathrm{E}-06$ & $2 \mathrm{E}-06$ & $4 \mathrm{E}-05$ & 0.018 & 1.055 & 1773.36 & $\begin{array}{l}\text { kritik, Turbulen } \\
\text { Kasar, bergerak, Super }\end{array}$ \\
\hline 14.31 & 0.86 & 0.71 & 0.204 & 3.08 & 0.0006 & $6 \mathrm{E}-06$ & $2 \mathrm{E}-06$ & $3 \mathrm{E}-05$ & 0.018 & 1.059 & 1845.61 & $\begin{array}{l}\text { kritik, Turbulen } \\
\text { Kasar, bergerak, Super }\end{array}$ \\
\hline 17.89 & 0.98 & 0.79 & 0.215 & 3.30 & 0.0006 & $5 \mathrm{E}-06$ & $2 \mathrm{E}-06$ & $3 \mathrm{E}-05$ & 0.018 & 1.065 & 1981.06 & kritik, Turbulen \\
\hline
\end{tabular}

Sumber: Hasil Studi Balai Sungai (2014)

Tabel 4 Keadaan hidraulik untuk kemiringan dasar saluran (i) : 0,0125 dan diameter butiranrata-rata : 0,6 mm $(0,0006 \mathrm{~m})$

\begin{tabular}{|c|c|c|c|c|c|c|c|c|c|c|c|c|}
\hline $\begin{array}{l}Q \\
\left(\mathrm{~m}^{3} / \mathrm{s}\right)\end{array}$ & $\begin{array}{l}\mathrm{h} \\
\text { (m) }\end{array}$ & $\begin{array}{l}R \\
(\mathrm{~m})\end{array}$ & $\begin{array}{l}U^{*} \\
(\mathrm{~m} / \mathrm{s})\end{array}$ & $\begin{array}{l}V \\
(\mathrm{~m} / \mathrm{s})\end{array}$ & $\begin{array}{l}\text { Ks } \\
\text { (m) }\end{array}$ & $\begin{array}{l}\partial \\
\left(\mathrm{m}^{2} / \mathrm{s}\right)\end{array}$ & $\begin{array}{l}0,3 \delta \\
\left(\mathrm{m}^{2} / \mathrm{s}\right)\end{array}$ & $\begin{array}{l}6, \partial \\
\left(\mathrm{m}^{2} / \mathrm{s}\right)\end{array}$ & $\begin{array}{l}\text { U*cr } \\
\text { Grafik } \\
\text { Shields }\end{array}$ & FR & $\mathbf{R e}$ & $\begin{array}{l}\text { Kondisi hidraulik } \\
\text { dan dasar sungai }\end{array}$ \\
\hline 5.37 & 0.45 & 0.40 & 0.22 & 3.06 & 0.0006 & $5 \mathrm{E}-06$ & $2 \mathrm{E}-06$ & 0.000031 & 0.018 & 1.46 & 1834 & $\begin{array}{l}\text { Kasar, bergerak, Super } \\
\text { kritik, Turbulen } \\
\text { Kasar, bergerak, Super }\end{array}$ \\
\hline 8.94 & 0.55 & 0.48 & 0.24 & 3.44 & 0.0006 & $5 \mathrm{E}-06$ & $1 \mathrm{E}-06$ & 0.000029 & 0.018 & 1.48 & 2066 & $\begin{array}{l}\text { kritik, Turbulen } \\
\text { Kasar, bergerak, Super }\end{array}$ \\
\hline 14.31 & 0.71 & 0.60 & 0.27 & 3.99 & 0.0006 & $4 \mathrm{E}-06$ & $1 \mathrm{E}-06$ & 0.000026 & 0.018 & 1.51 & 2394 & $\begin{array}{l}\text { kritik, Turbulen } \\
\text { Kasar, bergerak, Super }\end{array}$ \\
\hline 17.89 & 0.81 & 0.67 & 0.29 & 4.30 & 0.0006 & $4 \mathrm{E}-06$ & $1 \mathrm{E}-06$ & 0.000024 & 0.018 & 1.52 & 2577 & kritik, Turbulen \\
\hline
\end{tabular}

Sumber: Hasil Studi Balai Sungai (2014)

Tabel 5 Keadaan hidraulik untuk kemiringan dasar saluran (i) : 0,020 dan diameter butiran rata-rata : 0,6 mm $(0,0006 \mathrm{~m})$

\begin{tabular}{|c|c|c|c|c|c|c|c|c|c|c|c|c|}
\hline $\begin{array}{l}Q \\
\left(\mathrm{~m}^{3} / \mathrm{s}\right)\end{array}$ & $\begin{array}{l}h \\
(\mathrm{~m})\end{array}$ & $\begin{array}{l}R \\
(\mathrm{~m})\end{array}$ & $\begin{array}{l}\mathrm{U}^{*} \\
(\mathrm{~m} / \mathrm{s})\end{array}$ & $\begin{array}{l}V \\
(\mathrm{~m} / \mathrm{s})\end{array}$ & $\begin{array}{l}\text { Ks } \\
\text { (m) }\end{array}$ & $\begin{array}{l}\partial \\
\left(\mathrm{m}^{2} / \mathrm{s}\right)\end{array}$ & $\begin{array}{l}0,3 \delta \\
\left(\mathrm{m}^{2} / \mathrm{s}\right)\end{array}$ & $\begin{array}{l}6, \partial \\
\left(\mathrm{m}^{2} / \mathrm{s}\right)\end{array}$ & $\begin{array}{l}\text { U*cr } \\
\text { Grafik } \\
\text { Shields }\end{array}$ & FR & $\operatorname{Re}$ & $\begin{array}{l}\text { Kondisi hidraulik } \\
\text { dan dasar sungai }\end{array}$ \\
\hline 5.37 & 0.44 & 0.40 & 0.153 & 2.09 & 0.0006 & 7.6E-06 & 2.3E-06 & $4.56 \mathrm{E}-05$ & 0.018 & 1.01 & 1254 & $\begin{array}{l}\text { Kasar, bergerak, } \\
\text { Super kritik, Turbulen } \\
\text { Kasar, bergerak, }\end{array}$ \\
\hline 8.94 & 0.52 & 0.46 & 0.165 & 2.31 & 0.0006 & $7 \mathrm{E}-06$ & $2.1 \mathrm{E}-06$ & $4.23 \mathrm{E}-05$ & 0.018 & 1.02 & 1385 & $\begin{array}{l}\text { Super kritik, Turbulen } \\
\text { Kasar, bergerak, }\end{array}$ \\
\hline 12.52 & 0.60 & 0.52 & 0.175 & 2.51 & 0.0006 & $6.6 \mathrm{E}-06$ & $2 \mathrm{E}-06$ & 3.97E-05 & 0.018 & 1.03 & 1506 & $\begin{array}{l}\text { Super kritik, Turbulen } \\
\text { Kasar, bergerak, }\end{array}$ \\
\hline 14.31 & 0.64 & 0.55 & 0.180 & 2.61 & 0.0006 & $6.4 \mathrm{E}-06$ & $1.9 \mathrm{E}-06$ & $3.86 \mathrm{E}-05$ & 0.018 & 1.04 & 1563 & $\begin{array}{l}\text { Super kritik, Turbulen } \\
\text { Kasar, bergerak, }\end{array}$ \\
\hline 17.89 & 0.72 & 0.61 & 0.190 & 2.79 & 0.0006 & $6.1 \mathrm{E}-06$ & $1.8 \mathrm{E}-06$ & $3.67 \mathrm{E}-05$ & 0.018 & 1.05 & 1672 & Super kritik, Turbulen \\
\hline
\end{tabular}

Sumber: Hasil Studi Balai Sungai (2014) 
5 Alat untuk Penelitian

\section{a. Recirculating sediment flume}

Alat ini berukuran panjang $10,00 \mathrm{~m}$, lebar $0,40 \mathrm{~m}$ dan tinggi $0,60 \mathrm{~m}$, dilengkapi dengan pompa dengan kapsitas 17 liter/s. Pompa air dioperasikan untuk menyedot air yang debit nya diukur dengan alat ukur debit $\mathrm{V}$ north, dengan dikendalikan kran pelimpah. Kemiringan dasar saluran dan pintu dibagian hilir, berfungsi untuk mengontrol kedalaman aliran sesuai yang diinginkan. Bangunan ambang dasar di awal dan akhir saluran setinggi $20,00 \mathrm{~cm}$ dan selabar saluran $(40,00 \mathrm{~cm})$, berfungsi agar selama proses penyelidikan berlangsung tidak mengalami gerusan di bagian hulu dan hilir (Gambar, 1).

b. Point Gauge

Alat ini digunakan untuk mengukur kedalaman aliran dan gerusan.

c. Pintu air

Pintu air dipasang di bagian hulu untuk mengatur kebutuhan debit aliran, dan pintu di bagian hilir letaknya dihulu ambang dasar yang berfungsi untuk mengatur ketinggian muka air.

d. Model Pilar

Model pilar yang digunakan pada studi ini terbuat dari kayu yang ditipe sesuai model, kemudian dihaluskan dan dicat. Studi ini menggunakan tiga tipe pilar yaitu: dua silinder dengan diameter $3,50 \mathrm{~cm}$, tiang pancang (dengan jumlah tiang pancang enam) dengan diameter $1,28 \mathrm{~cm}$, dan tipe dinding penuh dengan dimensi panjang bagian atas $21 \mathrm{~cm}$, kemiringan dinding bagian hulu dan hilir 10/1. Model pilar diletakan di tengah flume. Jarak antara pilar ke pilar 3,00 $\mathrm{m}$ dan jarak pilar bagian hilir sampai pilar paling hilir 3,00 m, penyelidikan dilakukan secara simultan atau bersamaan. Hasil pengamatan di model antara pilar pertama, kedua dan ketiga ternyata tidak berpengaruh antara pilar satu dengan yang lainnya.

e. Stop watch

Alat ini digunakan untuk menentukan waktu tiap satuan waktu yang ditentukan untuk pengmbilan data kedalaman gerusan selama pengaliran berlangsung.

f. Kamera

Alat ini digunakan untuk pengambilan data serta dokumentasi selama studi.

g. Alat pengukur kecepatan aliran
Alat pengukur kecepatan aliran berupa pelampung atau curent meter berfungsi untuk mengetahui kecepatan aliran sehingga bisa untuk mendiskripsikan jenis aliran: kritik / sub kritik dan lain-lain.

\section{Tahapan Pelaksanaan Penelitian}

Pasang pipa paralon membujur saluran flume, yang setiap $10 \mathrm{~cm}$ dilubang sepanjang 10,00 m berfungsi sebagai awal pengujian untuk pengisian air sehingga susunan material dasar sungai tidak akan rusak akibat aliran dan sebagai resapan untuk membuat garis kontur gerusan lokal di sekitar pilar.

1 Pasang model pilar dengan jarak antar pilar 3,00 m.

2 Pasang alat ukur debit dibagian hulu, untuk memastikan besarnya debit aliran.

3 Susun bahan meterial dasar sungai setebal $20,00 \mathrm{~cm}$.

4 Atur kemiringan dasar saluran (dalam studiini diambil 0,006; 0,0125 dan 0,020.

5 Isi air secara perlahan lewat pipa paralon dalam material dasar sungai, hal ini dengan tujuan supaya susunan material dasar tidak rusak.

6 Alirkan debit air tertentu, yang telah diketahui kedalaman air diatas pisau alat ukur debit, untuk mengetahui kedalaman air digunakan alat point gauge.

7 Atur muka air di hilir dengan elevasi tertentu dengan diatur pintu bagian hilir.

8 Setelah kondisi aliran stabil, catat waktu dan perubahan kedalaman gerusan, dengan interval setiap satu menit dari 0 menit sampai menit ke sepuluh (10), interval lima menit dari menit ke 10 sampai menit ke 60, interval 15 menit dari menit ke 60 sampai menit ke 150 interval 30 menit dari menit ke 150 sampai menit 240, Untuk setiap pilar dilakukan pengukuran gerusan lokal empat titik (ujung depan, tengah depan, tengah hilir dan pilar bagian hilir).

9 Pendataan pola pergerakan sedimen saat running.

10 Pembuatan data kontur di sekitar pilar jembatan, dimulai dari elevasi dasar saluran tertinggi. Interval garis kontur dibuat interval $1 \mathrm{~cm}$.

11 Pasang garis kontur dengan benang mengikuti muka air pada dasar saluran.

12 Ukur gerusan terdalam apabila sudah tidak bisa di buat kontur.

13 Pendataan/pengambilan data kontur 
Pintu pelimpah
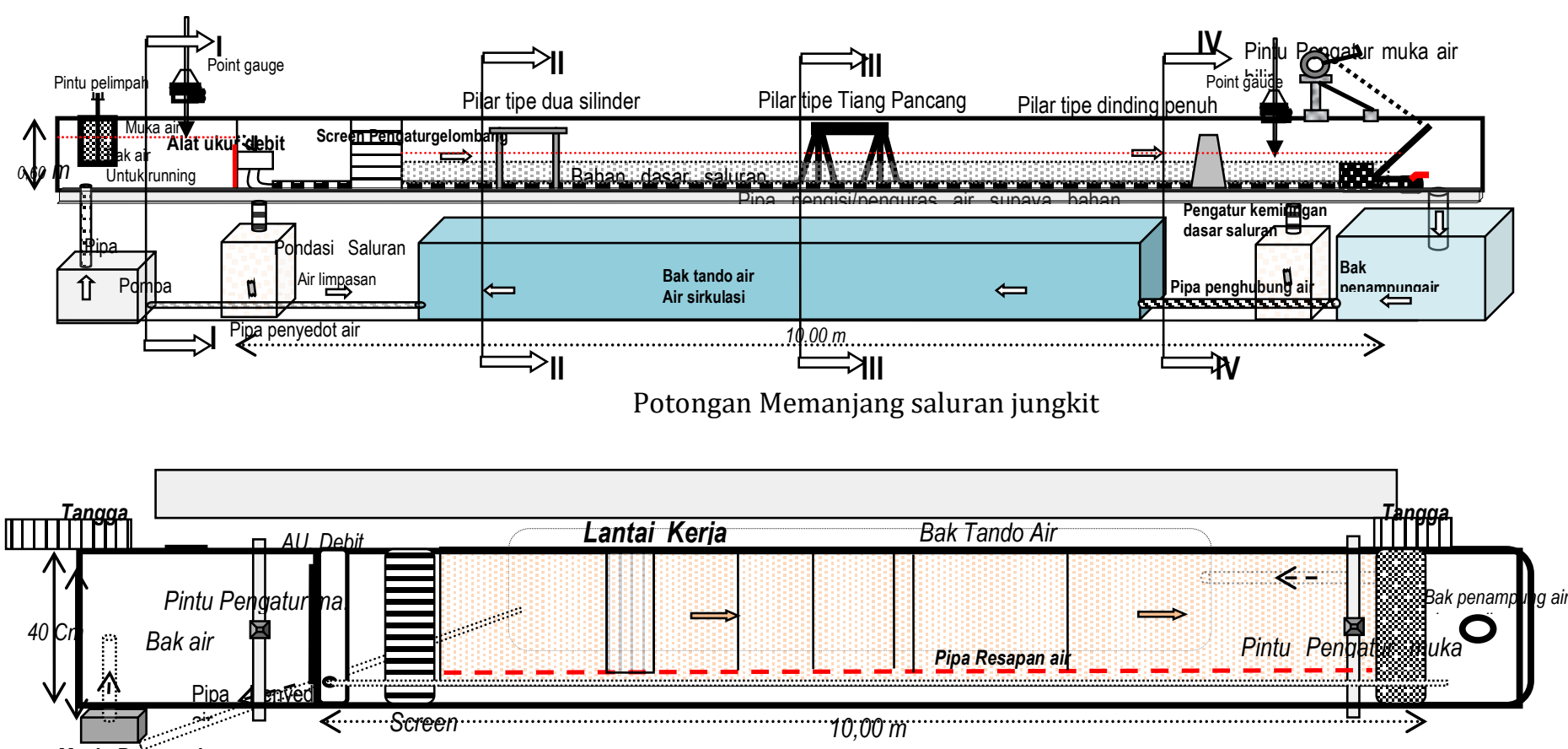

Mesin Pompa air

Denah saluran jungkit

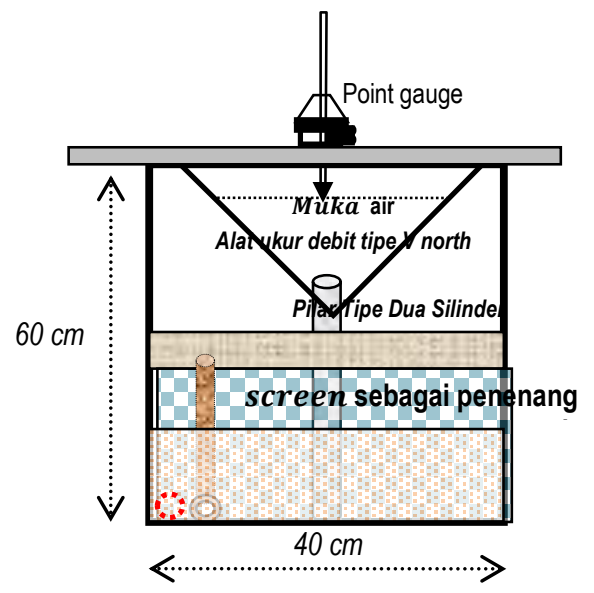

Potongan Melintang I-I

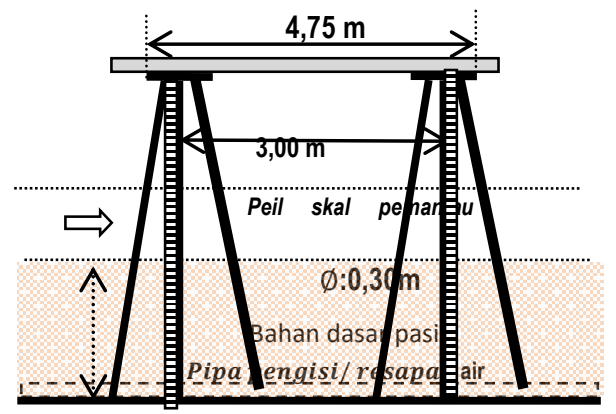

Pilar Tipe Tiang Pancang III-III

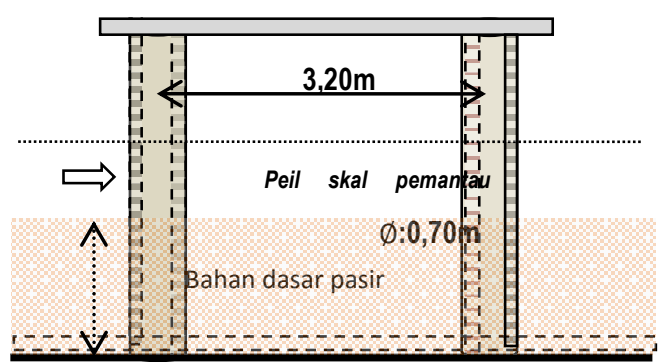

Pilar Tipe Dua Silinder II-II

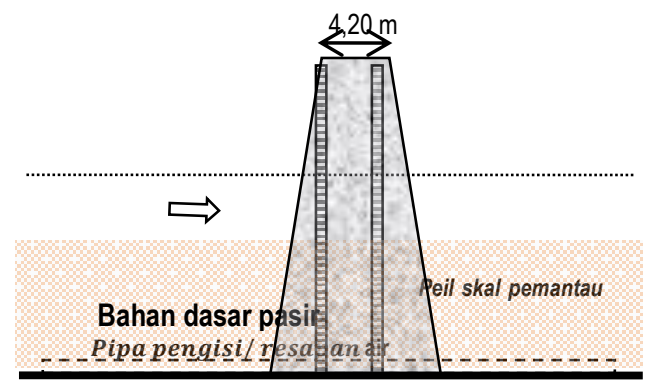

Gambar 1 Sketsa flume untuk studigerusan lokal dengan 3 (tiga) tipe pilar dimensi model. 


\section{METODOLOGI}

1 Sebelum melakukan pengujian dengan model fisik, dilakukan survei lapangan untuk mengetahuai berbagai tipe pilar jembatan yang ada di lapangan.

2 Penentuan skala model berdasarkan fasilitas laboratorium: lapangan, pompa air, peralatan pengukur hidraulik dan lain-lainnya.

3 Menentukan skala lapangan dengan skala di model fisik $\mathrm{H}=\mathrm{V}=1 / 20$.

4 Penelitian di laboratorium menggunakan recirculating sediment flume dengan ukuran panjang 10,00 m, lebar $0,40 \mathrm{~m}$ dan tinggi 0,60 $\mathrm{m}$, dilengkapi pompa dengan kapsitas 17 liter/s.

5 Penelitian menggunakan tiga tipe pilar sebagai berikut:

a. Tipe pilar dua silinder berdiameter $0,70 \mathrm{~m}$

b. Tipe pilar tiang pancang group, dengan diameter tiang pancang masing-masing 0,30 $\mathrm{m}$

c. Tipe pilar dinding penuh dengan dimensi panjang bagian atas $4,20 \mathrm{~m}$ kemiringan dinding bagian hulu dan hilir 10:1.

6 Perilaku gerusan yang ditinjau di sekitar pilar:

a. Material dasar sungai yang ditirukan kedalam model adalah pasir tanpa mengandung lumpur dengan diameter ratarata $(\mathrm{dm}): 0,60 \mathrm{~mm}, 0,80 \mathrm{~mm}$ dan $1,00 \mathrm{~mm}$.

b. Pola gerusan yang diamati disekitar pilar adalah kedalaman gerusan dengan kumulatip waktu interval setiap satu menit dari 0 menit sampai menit ke sepuluh (10), interval lima menit dari menit ke 10 sampai menit ke 60, interval 15 menit dari menit ke 60 sampai menit ke 150, interval 30 menit dari menit ke 150 sampai menit 240 .

7 Pembuatan model fisik

8 Pengaliran/Pengujian.

9 Kriteria Sifat Sebangun
Mengingat sifat pengaliran adalah dengan muka air bebas, percepatan gravitasi bumi adalah parameter yang dominan, sehingga persyaratan yang harus dipenuhi adalah sifat sebangun dinamik antara model dan prototip. Dalam hal ini bilangan Froude (Fr) di model harus sama dengan di prototip

Bilangan Froude $(F r)=\frac{\mathrm{V}}{\sqrt{\mathrm{gh}}}($ tanpa dimensi)

$\frac{\mathrm{V}}{\sqrt{\mathrm{gh}}}$ model $=\frac{\mathrm{V}}{\sqrt{\mathrm{gh}}}$ prototip

$\frac{V_{p}}{V_{m}}=\frac{(\sqrt{g h})}{(\sqrt{g h})} \frac{p}{m}$ atau $n_{v}=n g^{1 / 2} \cdot n^{1 / 2}$

Gaya gravitasi di prototip sama dengan di model, sehingga

$\mathrm{n}_{\mathrm{g}}=1$ sehingga $\mathrm{n}_{\mathrm{v}}=\mathrm{nh}^{1 / 2}$

$\mathrm{n}_{\mathrm{v}}=$ skala kecepatan

Keterangan notasi :

$\mathrm{v}=$ kecepatan aliran $(\mathrm{m} / \mathrm{s})$

$\mathrm{h}=$ kedalaman aliran $(\mathrm{m})$

$\mathrm{g}=$ percepatan gravitasi bumi $\left(\mathrm{m} / \mathrm{s}^{2}\right)$

Parameter yang lain dapat dirumuskan seperti pada Tabel 6 .

\section{HASIL DAN PEMBAHASAN}

\section{Batas bahasan}

1 Kondisi model dua dimensi

2 Analisa hidraulik secara teoritis digunakan untuk memperkirakan kedalaman air (h) sesuai debit pengaliran di saluran flume dan untuk memprediksi jenis alirannya.

3 Dalam bahasan ini semua parameter dalam dimensi model.

4 Dimensi debit aliran dalam model dua dimensi ini persatuan lebar $0,40 \mathrm{~m}$, bila dikoversikan ke satuan prototipe dengan skala $1 / 20$ dapat dilihat pada Tabel 7 .

Tabel 6 Parameter uji model hidrolik - fisik

\begin{tabular}{l|c|l}
\hline Parameter & Notasi & Skala \\
\hline Tinggi & $\mathrm{h}$ & $\mathrm{n}_{\mathrm{h}}=20$ \\
\hline Panjang & $\mathrm{l}$ & $\mathrm{n}_{\mathrm{l}}=20$ \\
\hline Kecepatan & $\mathrm{v}$ & $\mathrm{nv}=\mathrm{n}_{\mathrm{h}}^{1 / 2}=(20)^{1 / 2}=4,47$ \\
\hline Waktu & $\mathrm{t}$ & $\mathrm{nt}=\mathrm{n}_{\mathrm{h}^{1 / 2}}=(20)^{1 / 2}=4,47$ \\
\hline Debit & $\mathrm{Q}$ & $\mathrm{n}_{\mathrm{Q}}=\mathrm{n}_{\mathrm{h}}{ }^{5 / 2}=(20)^{5 / 2}=1788,85$ \\
\hline Angka kekasaran Manning & $\mathrm{n}$ & $\mathrm{nn}=\mathrm{n}_{\mathrm{h}^{1 / 6}}=(66,667)^{1 / 6}=2,013$ \\
\hline
\end{tabular}


Tabel 7 Hasil konversi satuan prototype ke model fisik.

\begin{tabular}{c|c|c}
\hline $\mathbf{q M}(\mathbf{I t} / \mathbf{s} / \mathbf{0 , 4 0} \mathbf{~ m})$ & $\mathbf{q P}\left(\mathbf{m}^{\mathbf{3}} / \mathbf{s} / \mathbf{8} \mathbf{~ m}\right)$ & $\mathbf{q P}\left(\mathbf{m}^{\mathbf{3}} / \mathbf{s} / \mathbf{1} \mathbf{~ m}\right)$ \\
\hline 3,00 & 5,37 & 0,67 \\
\hline 5,00 & 8,94 & 1,12 \\
\hline 7,00 & 12,52 & 1,57 \\
\hline 8,00 & 14,31 & 1,79 \\
\hline 10,00 & 17,89 & 2,24 \\
\hline
\end{tabular}

Keterangan:

$\mathrm{qM}=$ debit aliran di model

$\mathrm{qP}=$ debit aliran prototitpe

Gerusan yang terjadi di sekitar pilar jembatan adalah akibat dari sistem pusaran (horseshoe vortex system) yang timbul karena aliran terhadang pilar. Sistem pusaran yang menyebabkan lubang gerusan, berawal dari hulu pilar yaitu pada saat timbul komponen aliran dengan arah ke bawah.

Komponen aliran yang menuju ke dasar ini selanjutnya akan memtipe pusaran. Didekat dasar saluran komponen ini akan berbalik arah vertikal ke atas. Peristiwa ini diikuti dengan terbawanya material dasar sehingga tertipe aliran spiral yang akan menyebabkan gerusan dasar. Hal ini berlanjut hingga tercapai keseimbangan (Equilibrium)

Pilar jembatan biasanya dibangun pada bangunan melintang sungai saluran terbuka atau lainnya. Menurut Triatmojo (Hidraulika II) saluran terbuka adalah saluran dimana air mengalir dengan muka air bebas. Pada saluran variabel aliran tidak teratur baik terhadap ruang, maupun waktu. Variabel itu adalah tanpang lintang saluran, kekasaran, kemiringan dasar, belokan, debit aliran, dan sebagainya. Tipe aliran saluran terbuka menurut Triatmojo adalah turbulen karena kecepatan aliran dan kekasaran dinding yang besar. Aliran saluran terbuka akan turbulen apabila angka Reynold $\mathrm{Re}>500$ dan laminer apabila $\operatorname{Re}<500$.

Dalam penelitian ini alat yang digunakan sebagai media saluran terbuka adalah berupa saluran jungkit (Recirculating sediment flume), berukuran panjang $10,00 \mathrm{~m}$, lebar $0,40 \mathrm{~m}$ dan tinggi $0,60 \mathrm{~m}$, dilengkapi pompa dengan kapasitas 17 liter/s. dan dilakukan di Laboratorium.

Pengamatan yang dilakukan ada beberapa parameter antara lain : material dasar dengan $\mathrm{dm}_{50}$ :0,60 $\mathrm{mm}, 0,80 \mathrm{~mm}$ dan $1,00 \mathrm{~mm}$ dengan variasi debit aliran: $5,37 \mathrm{~m}^{3} / \mathrm{s}, 8,94 \mathrm{~m}^{3} / \mathrm{s}, 12,52 \mathrm{~m}^{3} / \mathrm{s}$, $14,31 \mathrm{~m}^{3} / \mathrm{s}$, dan $17,89 \mathrm{~m}^{3} / \mathrm{s}$, kemiringan dasar (i) ada tiga variasi $(0,006,0,0125$ dan 0,020) dan tiga tipe bentuk pilar antara lain: a) dua silinder, b) tiang pancang dan c) dinding penuh yang dilakukan secara simultan. Pada tulisan ini ditampilkan hasil salah satu contoh pengaliran debit $12,52 \mathrm{~m}^{3} / \mathrm{s}$, dengan kemiringan dasar saluran 0,006 , diameter bahan dasar butiran (d $50=0,6$ $\mathrm{mm}$ ), dan hasil untuk (i) dasar saluran 0.020 dengan $\left(\mathrm{dm}_{50}=1,00 \mathrm{~mm}\right) \quad$ Hasil analisis pengamatan dari tiga tipe pilar meliputi: pilar tipe dua silinder (Gambar 2), pilar tipe tiang pancang (Gambar 3), danpilar tipe dinding penuh (Gambar 4) disajikan dalam Tabel 8, 9 dan 10 sebagai berikut:

\section{Tipe pilar dua silinder}

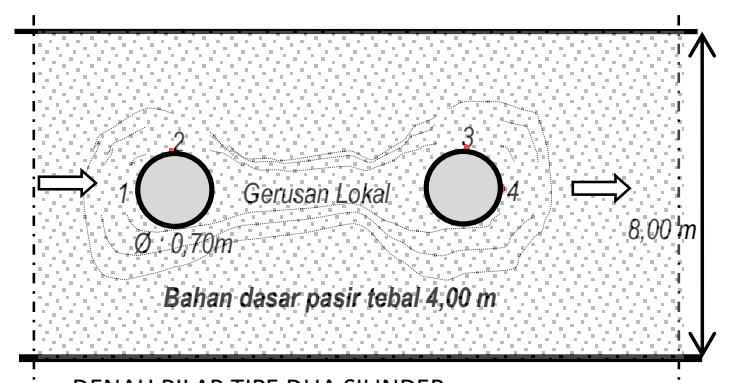

DENAH PILAR TIPE DUA SILINDER

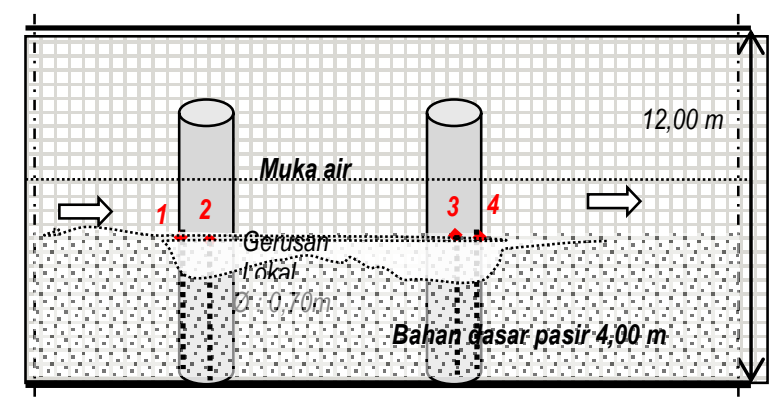

POTONGAN MEMANJANG PILAR TIPE DUA SILINDER

Gambar 2 Sketsa gerusan lokal pada pilar tipe dua silinder 
Tabel 8 Hasil Analisis pengamatan untuk kemiringan dasar saluran (i) : 0,006, dengan bahan dasar pasir. pilar tipe dua silinder, Debit aliran $12,52 \mathrm{~m}^{3} / \mathrm{s}$, Bahan dasar pasir halus $(\mathrm{dm}=0,60 \mathrm{~mm}$ )

\begin{tabular}{|c|c|c|c|c|c|c|}
\hline No Titik & \multicolumn{5}{|c|}{ Kondisi Perubahan dasar dari menit ke menit } & \multirow{2}{*}{$\begin{array}{c}\text { Kesimpulan } \\
\text { Kecenderungan } \\
\text { perubahan dasar }\end{array}$} \\
\hline $\begin{array}{l}\text { Penga } \\
\text { matan }\end{array}$ & $0-10$ & $10-20$ & $20-40$ & $40-60$ & 60 - selesai (180) & \\
\hline 1 & $\begin{array}{l}\text { Terjadi gerusan } \\
\text { mendadak, mencapai } \\
-0,60 \mathrm{~m} \text { dari menit } \\
\text { ke } 1 \mathrm{~s} / \mathrm{d} \text { menit ke } 6, \\
\text { setelah menit ke } 7 \\
\text { gerusan mengecil s/d } \\
0,30 \mathrm{~m} \text { bentuknya } \\
\text { bergelombang } \\
\text { terutama pada menit } \\
\text { pertama langsung ke } \\
0,52 \mathrm{~m}\end{array}$ & $\begin{array}{l}\text { Gerusan tidak stabil, } \\
\text { dasar saluran } \\
\text { bergelombang, naik } \\
\text { turun cenderung } \\
\text { turun dari }-0,50 \mathrm{~s} / \mathrm{d} \text { - } \\
0,34 \mathrm{~m}\end{array}$ & $\begin{array}{l}\text { Gerusan cenderung } \\
\text { menurun liniair dari } \\
-0,34 \mathrm{~s} / \mathrm{d}-0,40 \mathrm{~m}\end{array}$ & $\begin{array}{l}\text { Gerusan } \\
\text { cenderung stabil } \\
\text { liniair dari }-0,40 \\
\text { s/d }-0,42 \mathrm{~m} \text {, }\end{array}$ & $\begin{array}{l}\text { Gerusan mulai } \\
\text { stabil, tetapi } \\
\text { cenderung turun } \\
\text { dari kedalaman } \\
\text { gerusan - 0,42 } \\
\text { s/d-0,60 m }\end{array}$ & \multirow{4}{*}{$\begin{array}{l}\text { - Gerusan terdalam } \\
\text { berjalan pada titik } \\
\text { pengamatan no.2. } \\
\text { gerusan } \\
\text { terdalam - } 0,74 \mathrm{~m} \\
\text { - Gerusan terdalam } \\
\text { urutan ke } 2 \\
\text { berjalan pada titik } \\
\text { pengamatan no . } 3 \\
\text { Gerusan terdalam } \\
\text {-0,66 m } \\
\text { - Gerusan terdalam } \\
\text { urutan ke } 3 \\
\text { berjalan pada titik } \\
\text { pengamatan no } .1 \\
\text { gerusan terdalam } \\
\text { - 0,60m } \\
\text { - Gerusan terdalam } \\
\text { urutan ke } 4 \\
\text { berjalan pada titik } \\
\text { pengamatan no } 4 \\
\text { gerusan terdalam } \\
\text { - 0,36 m } \\
\text { Lama pengaliran } \\
\text { sampai dalam } \\
\text { kondisi dasar } \\
\text { saluran stabil } 4,00 \\
\text { jam }\end{array}$} \\
\hline 2 & $\begin{array}{l}\text { Terjadi gerusan } \\
\text { mendadak, mencapai } \\
-0,76 \mathrm{~m} \text { dari menit } \\
\text { ke } 1 \mathrm{~s} / \mathrm{d} \text { menit ke } 4, \\
\text { setelah menit ke } 5 \\
\text { gerusan mengecil s/d } \\
-0,39 \text { bentuknya } \\
\text { bergrlombang } \\
\text { terutama pada menit } \\
\text { pertama langsung ke } \\
-0,60 \mathrm{~m}\end{array}$ & $\begin{array}{l}\text { Gerusan tidak stabil, } \\
\text { dasar saluran hampir } \\
\text { lurus cenderung } \\
\text { turun, dari }-0,38 \mathrm{~s} / \mathrm{d} \\
-0,40 \mathrm{~m}\end{array}$ & $\begin{array}{l}\text { Gerusan cenderung } \\
\text { menurun } \\
\text { bergelombang dari - } \\
0,40 \mathrm{~s} / \mathrm{d}-0,50 \mathrm{~m} \text {, }\end{array}$ & $\begin{array}{l}\text { Gerusan } \\
\text { cenderung } \\
\text { menurun } \\
\text { bergelombang } \\
\text { dari }-0,50 \mathrm{~s} / \mathrm{d}- \\
0,56 \mathrm{~m} \text {, }\end{array}$ & $\begin{array}{l}\text { Gerusan mulai } \\
\text { stabil, tetapi } \\
\text { cenderung turun, } \\
\text { hampir } \\
\text { berbentuk garis } \\
\text { liniair } \\
\text { dari kedalaman } \\
\text { gerusan }-0,56 \\
\mathrm{~s} / \mathrm{d}-0,74 \mathrm{~m}\end{array}$ & \\
\hline 3 & $\begin{array}{l}\text { Terjadi gerusan } \\
\text { mendadak, mencapai } \\
-0,48 \text { m dari menit } \\
\text { ke } 1 \mathrm{~s} / \mathrm{d} \text { menit ke } 4, \\
\text { setelah menit ke } 5 \\
\text { gerusan mengecil s/d } \\
-0,34 \text { m bentuknya } \\
\text { bergrlombang } \\
\text { terutama pada menit } \\
\text { pertama langsung ke } \\
-0,42 \mathrm{~m} \\
\end{array}$ & $\begin{array}{l}\text { Gerusan stabil, dasar } \\
\text { saluran hampir datar, } \\
\text { cenderung turun, } \\
0,42 \mathrm{~s} / \mathrm{d}-0,30 \mathrm{~m}\end{array}$ & $\begin{array}{l}\text { Gerusan cenderung } \\
\text { menurun } \\
\text { bergelombang dari - } \\
0,30 \mathrm{~s} / \mathrm{d}-0,38 \mathrm{~m}\end{array}$ & $\begin{array}{l}\text { Gerusan } \\
\text { cenderung } \\
\text { menurun liniair } \\
\text { dari }-0,39 \mathrm{~s} / \mathrm{d}- \\
0,48 \mathrm{~m},\end{array}$ & $\begin{array}{l}\text { Gerusan mulai } \\
\text { stabil, tetapi } \\
\text { cenderung turun } \\
\text { dari kedalaman } \\
\text { gerusan - 0,48 } \\
\text { s/d -0,66 m }\end{array}$ & \\
\hline 4 & $\begin{array}{l}\text { Terjadi gerusan } \\
\text { mendadak, mencapai } \\
-0,60 \mathrm{~m} \text { dari menit } \\
\text { ke } 1 \mathrm{~s} / \mathrm{d} \text { menit ke } 2 \text {, } \\
\text { setelah menit ke } 3 \\
\text { gerusan mengecil s/d } \\
-0,20 \mathrm{~m} \text { bentuknya } \\
\text { bergelombang } \\
\text { terutama pada menit } \\
\text { pertama langsung ke } \\
-0,40 \mathrm{~m}\end{array}$ & $\begin{array}{l}\text { Gerusan bertambah } \\
\text { besar / turun, dasar } \\
\text { saluran } \\
\text { bergelombang lurus - } \\
0,20 \mathrm{~m} \mathrm{~s} / \mathrm{d}-0,14 \mathrm{~m}\end{array}$ & $\begin{array}{l}\text { Gerusan cenderung } \\
\text { naik } \\
\text { bergelombang dari } \\
-0,14 \mathrm{~s} / \mathrm{d}-0,34 \mathrm{~m}\end{array}$ & $\begin{array}{l}\text { Gerusan } \\
\text { bergelombang } \\
\text { cenderung naik } \\
\text { dari }-0,34 \mathrm{~s} / \mathrm{d} \text { - } \\
0,28 \mathrm{~m} .\end{array}$ & $\begin{array}{l}\text { Gerusan mulai } \\
\text { stabil, tetapi } \\
\text { cenderung turun } \\
\text { dari kedalaman } \\
\text { gerusan }-0,28 \mathrm{~s} / \mathrm{d} \\
-0,36 \mathrm{~m}\end{array}$ & \\
\hline
\end{tabular}

2. Tipe pilar tiang pancang

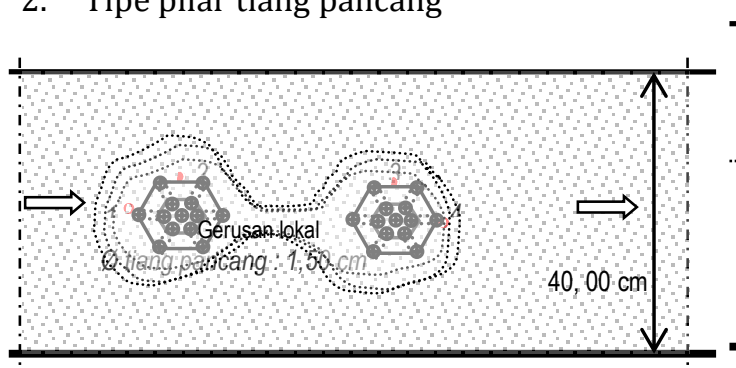

Denah Pilar Tipe Tiang Pancang

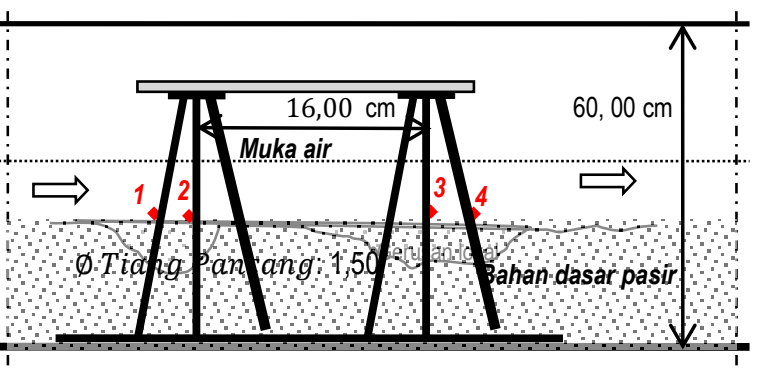

Potongan Memanjang Pilar Tipe Tiang Pancang

Gambar 3 Sketsa gerusan lokal pada Pilar tipe Tiang Pancang 
Tabel 9 Hasil Analisis pengamatan untuk kemiringan dasar saluran (i) : 0,006, dengan bahan dasar pasir halus, pilar tipe tiang pancang, debit aliran $12,52 \mathrm{~m}^{3} / \mathrm{s}$, bahan dasar pasir halus $\left(d_{m} 50: 0,60 \mathrm{~mm}\right)$

\begin{tabular}{|c|c|c|c|c|c|c|}
\hline No Titik & \multicolumn{5}{|c|}{ Kondisi Perubahan dasar dari menit ke menit } & Kesimpulan \\
\hline $\begin{array}{l}\text { Penga } \\
\text { matan }\end{array}$ & $0-10$ & 10- 20 & $20-40$ & $40-60$ & 60 - selesai (180) & $\begin{array}{l}\text { Kecenderungan } \\
\text { perubahan dasar }\end{array}$ \\
\hline 1 & $\begin{array}{l}\text { Terjadi gerusan } \\
\text { mendadak, } \\
\text { mencapai - 0,80 m, } \\
\text { terutama pada } \\
\text { menit pertama } \\
\text { langsung ke }-0,60 \mathrm{~m}\end{array}$ & $\begin{array}{l}\text { Gerusan tidak } \\
\text { stabil, dasar } \\
\text { saluran } \\
\text { bergelombang, } \\
\text { naik turun } \\
\text { cenderung naik } \\
\text { Dari }-0,80 \mathrm{~s} / \mathrm{d} \\
-1,00 \mathrm{~m}\end{array}$ & $\begin{array}{l}\text { Gerusan } \\
\text { cenderung } \\
\text { menurun } \\
\text { bergelombang } \\
\text { dari }-1,00 \mathrm{~s} / \mathrm{d} \\
-1,10 \mathrm{~cm} \text {, }\end{array}$ & $\begin{array}{l}\text { Gerusan } \\
\text { cenderung } \\
\text { menurun } \\
\text { bergelombang } \\
\text { dari }-0,80 \mathrm{~s} / \mathrm{d} \\
-0,90 \mathrm{~m},\end{array}$ & $\begin{array}{l}\text { Gerusan mulai } \\
\text { stabil, tetapi } \\
\text { cenderung turun } \\
\text { Dari kedalaman } \\
\text { gerusan } \\
-0,95 \mathrm{~s} / \mathrm{d}-1,40 \mathrm{~m}\end{array}$ & \multirow{4}{*}{$\begin{array}{l}\text { - Gerusan terdalam } \\
\text { berjalan pada titik } \\
\text { pengamatan no .1. } \\
\text { gerusan terdalam - } \\
\text { 1,40 m } \\
\text { - Gerusan terdalam } \\
\text { urutan ke } 2 \\
\text { berjalan pada titik } \\
\text { pengamatan no . } 2 \\
\text { Gerusan terdalam - } \\
\text { 1,32m } \\
\text { - Gerusan terdalam } \\
\text { urutan ke } 3 \\
\text { berjalan pada titik } \\
\text { pengamatan no . } 3 \\
\text { Gerusan terdalam - } \\
\text { 1,60 m } \\
\text { Gerusan terdalam } \\
\text { urutan ke } 4 \\
\text { berjalan pada titik } \\
\text { pengamatan no .4 } \\
\text { Gerusan terdalam - } \\
\text { 0,82m } \\
\text { Lama pengaliran } \\
\text { sampai dalam } \\
\text { kondisi dasar saluran } \\
\text { stabil } 4,00 \text { jam } \\
\text { - }\end{array}$} \\
\hline 2 & $\begin{array}{l}\text { Terjadi gerusan } \\
\text { mendadak, } \\
\text { mencapai - 0,86 m, } \\
\text { terutama pada } \\
\text { menit pertama } \\
\text { mencapai } \\
0,64 \mathrm{~m}\end{array}$ & $\begin{array}{l}\text { Gerusan tidak } \\
\text { stabil, dasar } \\
\text { saluran hampir } \\
\text { lurus cenderung } \\
\text { turun, dari - 0,86 } \\
\text { s/d - 0,88m }\end{array}$ & $\begin{array}{l}\text { Gerusan } \\
\text { cenderung } \\
\text { menurun liniair } \\
\text { dari }-0,88 \mathrm{~s} / \mathrm{d} \\
-0.96 \mathrm{~m}\end{array}$ & $\begin{array}{l}\text { Gerusan } \\
\text { cenderung } \\
\text { menurun liniair } \\
\text { dari }-0,96 \mathrm{~s} / \mathrm{d} \\
-1,02 \mathrm{~m} \text {, }\end{array}$ & $\begin{array}{l}\text { Gerusan mulai } \\
\text { stabil, tetapi } \\
\text { cenderung turun } \\
\text { dari kedalaman } \\
\text { gerusan } \\
-1,02 \mathrm{~s} / \mathrm{d}-1,32 \mathrm{~m}\end{array}$ & \\
\hline 3 & $\begin{array}{l}\text { Terjadi gerusan } \\
\text { mendadak, } \\
\text { mencapai -0,64m, } \\
\text { terutama pada } \\
\text { menit pertama } \\
\text { mencapai } \\
0,56 \mathrm{~m}\end{array}$ & $\begin{array}{l}\text { Gerusan dasar } \\
\text { saluran } \\
\text { bergelombang, } \\
\text { cenderung turun, } \\
-0,64 \mathrm{~s} / \mathrm{d}-0,76 \\
\mathrm{~m}\end{array}$ & $\begin{array}{l}\text { Gerusan } \\
\text { cenderung } \\
\text { menurun liniair } \\
\text { dari }-0,76 \mathrm{~s} / \mathrm{d} \\
-0,78 \mathrm{~m}\end{array}$ & $\begin{array}{l}\text { Gerusan } \\
\text { cenderung } \\
\text { menurun } \\
\text { bergelombang } \\
\text { dari }-0,78 \mathrm{~s} / \mathrm{d} \\
-0,82 \mathrm{~m} \text {, }\end{array}$ & $\begin{array}{l}\text { Gerusan mulai } \\
\text { stabil, tetapi } \\
\text { cenderung turun } \\
\text { dari kedalaman } \\
\text { gerusan } \\
-0,82 \mathrm{~s} / \mathrm{d}-1,06 \mathrm{~m}\end{array}$ & \\
\hline 4 & $\begin{array}{l}\text { Terjadi gerusan } \\
\text { mendadak, } \\
\text { mencapai }-0,46 \mathrm{~m}, \\
\text { terutama pada } \\
\text { menit pertama } \\
\text { mencapai } \\
-0,26 \mathrm{~m}\end{array}$ & $\begin{array}{l}\text { Gerusan stabil, } \\
\text { dasar saluran } \\
\text { hampir datar - } \\
0,26 \mathrm{~s} / \mathrm{d}-0,54 \mathrm{~m}\end{array}$ & $\begin{array}{l}\text { Gerusan } \\
\text { cenderung naik } \\
\text { bergelombang } \\
\text { dari-0,54 s/d } \\
-0,80 \mathrm{~m}\end{array}$ & $\begin{array}{l}\text { Gerusan } \\
\text { cenderung naik } \\
\text { liniair dari }-0,80 \\
\text { s/d-0,48m, }\end{array}$ & $\begin{array}{l}\text { Gerusan mulai } \\
\text { stabil, tetapi } \\
\text { cenderung turun } \\
\text { dari kedalaman } \\
\text { gerusan } \\
0,48 \mathrm{~s} / \mathrm{d}-0,82 \mathrm{~m}\end{array}$ & \\
\hline
\end{tabular}

3. Tipe pilar dinding penuh

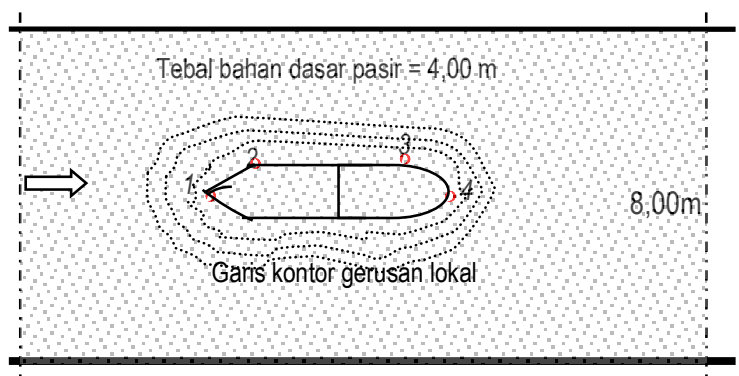

Denah Pilar Tipe Dinding Penuh

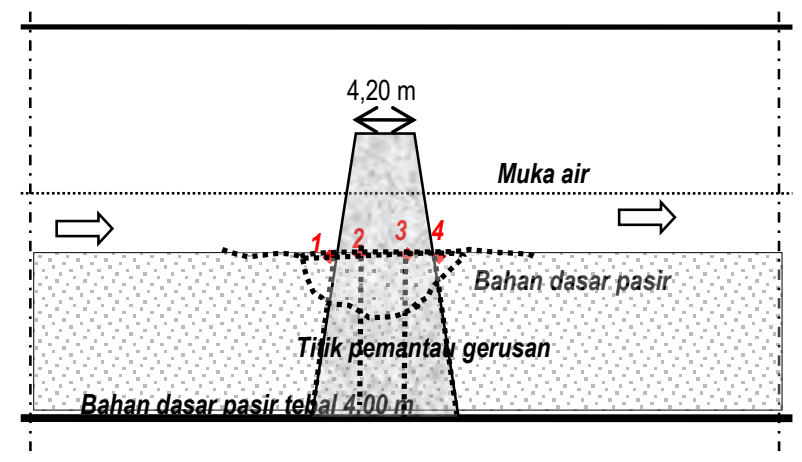

Potongan Memanjang Pilar Tipe Dinding Penuh

Gambar 4 Sketsa gerusan lokal pada Pilar tipe Dinding Penuh. 
Tabel 10 Analisa pengamatan untuk kemiringan dasar saluran (i) : 0,006, dengan bahan dasar pasir halus, pilar tipe dinding penuh, debit aliran $12,52 \mathrm{~m}^{3} / \mathrm{s}$, bahan dasar pasir halus $(\mathrm{dm}: 0,60 \mathrm{~mm})$

\begin{tabular}{|c|c|c|c|c|c|c|}
\hline \multirow{2}{*}{$\begin{array}{c}\text { No } \\
\text { Titik } \\
\text { Penga } \\
\text { matan }\end{array}$} & \multicolumn{5}{|c|}{ Kondisi Perubahan dasar dari menit ke menit } & \multirow{2}{*}{$\begin{array}{c}\text { Kesimpulan } \\
\text { Kecenderungan } \\
\text { perubahan dasar }\end{array}$} \\
\hline & $0-10$ & 10- 20 & $20-40$ & $40-60$ & 60 - selesai (180) & \\
\hline 1 & $\begin{array}{l}\text { Terjadi gerusan } \\
\text { mendadak, } \\
\text { mencapai - 1,04 m, } \\
\text { terutama pada } \\
\text { menit ke } 2 \text { s/d } 6 \\
\text { gerusan stabil, pada } \\
\text { menit pertama } \\
\text { langsung ke -0,90 m }\end{array}$ & $\begin{array}{l}\text { Gerusan tidak } \\
\text { stabil, dasar } \\
\text { saluran } \\
\text { bergelombang, } \\
\text { naik turun } \\
\text { cenderung naik } \\
\text { Dari -1,24 s/d } \\
\text { - 1,24 m }\end{array}$ & $\begin{array}{l}\text { Gerusan } \\
\text { cenderung } \\
\text { bergelombang } \\
\text { stabil dari - 1,20 } \\
\text { s/d -1,20 m, }\end{array}$ & $\begin{array}{l}\text { Gerusan } \\
\text { cenderung } \\
\text { menurun liniair } \\
\text { dari }-1,20 \mathrm{~s} / \mathrm{d} \\
-1,26 \mathrm{~m} \text {, }\end{array}$ & $\begin{array}{l}\text { Gerusan mulai } \\
\text { stabil, tetapi } \\
\text { cenderung turun } \\
\text { dari kedalaman } \\
\text { gerusan - 1,26 s/d } \\
-1,48 \mathrm{~m}\end{array}$ & \multirow{4}{*}{$\begin{array}{l}\text { - Gerusan terdalam } \\
\text { berjalan pada titik } \\
\text { pengamatan no } .1 . \\
\text { gerusan terdalam } \\
\text {-1,48 m } \\
\text { - Gerusan terdalam } \\
\text { urutan ke } 2 \text { berjalan } \\
\text { pada titik pengamatan } \\
\text { no } .2 \text { gerusan } \\
\text { terdalam - } 1,40 \mathrm{~cm} \\
\text { - Gerusan terdalam } \\
\text { urutan ke } 3 \text { berjalan } \\
\text { pada titik pengamatan } \\
\text { no } .3 \text { gerusan } \\
\text { terdalam - } 0,96 \text { m } \\
\text { - Gerusan terdalam } \\
\text { urutan ke } 4 \text { berjalan } \\
\text { pada titik pengamatan } \\
\text { no } 4 \text { gerusan } \\
\text { terdalam - } 0,50 \text { m } \\
\text { Lama pengaliran } \\
\text { sampai dalam kondisi } \\
\text { dasar saluran stabil } \\
4,00 \text { jam }\end{array}$} \\
\hline 2 & $\begin{array}{l}\text { Terjadi gerusan } \\
\text { mendadak, } \\
\text { mencapai - 1,24 m, } \\
\text { terutama pada } \\
\text { menit pertama } \\
\text { mencapai 0,80 m, } \\
\text { menit ke } 2 \text { - ke } 10 \\
\text { terjadi gerusan } \\
\text { hampir merata }\end{array}$ & $\begin{array}{l}\text { Gerusan tidak } \\
\text { stabil, dasar } \\
\text { saluran } \\
\text { bergelombang } \\
\text { cenderung naik, } \\
\text { dari }-1,24 \mathrm{~s} / \mathrm{d} \\
\text { - } 1,14 \mathrm{~m}\end{array}$ & $\begin{array}{l}\text { Gerusan } \\
\text { cenderung } \\
\text { menurun liniair } \\
\text { dari } 1,14 \mathrm{~s} / \mathrm{d} \\
-1,20 \mathrm{~m} \text {, }\end{array}$ & $\begin{array}{l}\text { Gerusan } \\
\text { cenderung stabil } \\
\text { liniair dari - 1,20 } \\
\text { s/d-1,20m, }\end{array}$ & $\begin{array}{l}\text { Gerusan mulai } \\
\text { stabil, tetapi } \\
\text { cenderung turun } \\
\text { dari kedalaman } \\
\text { gerusan - 1,20 s/d } \\
-1,40 \mathrm{~m}\end{array}$ & \\
\hline 3 & $\begin{array}{l}\text { Terjadi gerusan } \\
\text { mendadak, } \\
\text { mencapai }-0,78 \mathrm{~m} \text {, } \\
\text { terutama pada } \\
\text { menit pertama } \\
\text { mencapai - } 0,60 \mathrm{~m}\end{array}$ & $\begin{array}{l}\text { Gerusan stabil, } \\
\text { dasar saluran } \\
\text { hampir datar, } \\
\text { cenderung turun, - } \\
0,78 \mathrm{~s} / \mathrm{d} \\
0,80 \mathrm{~m} \\
\end{array}$ & $\begin{array}{l}\text { Gerusan } \\
\text { cenderung naik } \\
\text { bergelombang } \\
\text { dari }-0.80 \mathrm{~s} / \mathrm{d} \\
-0,72 \mathrm{~m}\end{array}$ & $\begin{array}{l}\text { Gerusan } \\
\text { cenderung } \\
\text { menurun liniair } \\
\text { dari }-0,72 \mathrm{~s} / \mathrm{d} \text { - } \\
0,80 \mathrm{~m},\end{array}$ & $\begin{array}{l}\text { Gerusan mulai } \\
\text { stabil, tetapi } \\
\text { cenderung turun } \\
\text { dari kedalaman } \\
\text { gerusan - 0,80 s/d } \\
-0,96 \mathrm{~m}\end{array}$ & \\
\hline 4 & $\begin{array}{l}\text { Terjadi gerusan } \\
\text { mendadak, } \\
\text { mencapai - 0,20 m, } \\
\text { terutama pada } \\
\text { menit pertama } \\
\text { mencapai 0,10 m } \\
\text { setelah menit ke } 2 \\
\text { s/d 5, gerusan naik } \\
\text { menuju kembali ke } \\
0,00 \text { m }\end{array}$ & $\begin{array}{l}\text { Gerusan stabil, } \\
\text { dasar saluran } \\
\text { hampir datar } 0,00 \\
\text { s/d - 0,00 m }\end{array}$ & $\begin{array}{l}\text { Gerusan } \\
\text { cenderung turun } \\
\text { bergelombang } \\
\text { dari } 0,00 \mathrm{~s} / \mathrm{d} \\
0,20 \mathrm{~m}\end{array}$ & $\begin{array}{l}\text { Gerusan } \\
\text { cenderung } \\
\text { menurun liniair } \\
\text { dari }-0,20 \mathrm{~s} / \mathrm{d}- \\
0,10 \mathrm{~m}, \\
\text { bergelombang }\end{array}$ & $\begin{array}{l}\text { Gerusan mulai } \\
\text { stabil, tetapi } \\
\text { cenderung turun } \\
\text { Dari kedalaman } \\
\text { gerusan }-0,10 \mathrm{~s} / \mathrm{d} \\
-0,50 \mathrm{~m}\end{array}$ & \\
\hline
\end{tabular}

Sumber: Hasil Studi Balai Sungai (2014)

Dimensi gerusan terdalam untuk masing-masing tipe pilar disajikan dalam Tabel 11 sebagai berikut:

Tabel 11 Dimensi gerusan untuk bahan dasar pasir halus dengan kemiringan dasar saluran 0,006

a) Tipe pilar Dua Silinder

\begin{tabular}{ccccccc}
\hline \multirow{2}{*}{$\begin{array}{c}\text { Debit } \\
\left(\mathrm{m}^{3} / \mathrm{s}\right)\end{array}$} & \multicolumn{2}{c}{ Panjang gerusan(m) } & \multicolumn{2}{c}{ Lebar gerusan $(\mathrm{m})$} & \multirow{2}{\text{Gerusan}}{$\begin{array}{c}\text { No. Titik } \\
\text { terdalam }(\mathrm{m})\end{array}$} & $\begin{array}{c}\text { Pengamatan } \\
\text { Gerusan terdalam }\end{array}$ \\
\cline { 2 - 4 } & $\mathrm{L}_{1}$ & $\mathrm{~L}_{2}$ & $\mathrm{~B}_{1}$ & $\mathrm{~B}_{2}$ & & 2 \\
5,37 & 0,40 & 1,60 & 0,60 & 0,60 & 1,04 & 2 \\
8,94 & 0,80 & 2,00 & 1,00 & 1,00 & 1,16 & 2 \\
12,52 & 1,00 & 2,20 & 1,40 & 1,40 & 1,40 & 2 \\
14,31 & 1,20 & 2,40 & 1,60 & 1,60 & 1,46 & 2 \\
17,89 & 1,30 & 2,60 & 1,80 & 1,80 & 1,58 & \\
\hline
\end{tabular}

Sumber: Hasil Studi Balai Sungai (2014) 
b) Tipe Pilar Tiang Pancang

\begin{tabular}{|c|c|c|c|c|c|c|}
\hline \multirow{2}{*}{$\begin{array}{l}\text { Debit } \\
\left(\mathrm{m}^{3} / \mathrm{s}\right)\end{array}$} & \multicolumn{2}{|c|}{ Panjang gerusan $(\mathrm{m})$} & \multicolumn{2}{|c|}{ Lebar gerusan (m) } & \multirow{2}{*}{$\begin{array}{c}\text { Gerusan } \\
\text { terdalam (m) }\end{array}$} & \multirow{2}{*}{$\begin{array}{c}\text { No. Titik } \\
\text { Pengamatan } \\
\text { Gerusan terdalam }\end{array}$} \\
\hline & $\mathrm{L}_{1}$ & $\mathrm{~L}_{2}$ & $\mathrm{~B}_{1}$ & $\mathrm{~B}_{2}$ & & \\
\hline 5,37 & 1,00 & 2,00 & 2,00 & 2,00 & 2,20 & 2 \\
\hline 8,94 & 1,50 & 3,00 & 3,00 & 3,00 & 2,60 & 2 \\
\hline 12,52 & 2,00 & 4,00 & 4,00 & 4,00 & 3,50 & 2 \\
\hline 14,31 & 3,00 & 5,00 & 4,00 & 4,00 & 3,90 & 2 \\
\hline 17,89 & 4,00 & 6,00 & 4,00 & 4,00 & 4,30 & 2 \\
\hline
\end{tabular}

Sumber: Hasil Studi Balai Sungai (2014)

c) Tipe pilar Dinding Penuh

\begin{tabular}{|c|c|c|c|c|c|c|}
\hline \multirow{2}{*}{$\begin{array}{l}\text { Debit } \\
\left(\mathrm{m}^{3} / \mathrm{s}\right)\end{array}$} & \multicolumn{2}{|c|}{ Panjang gerusan(m) } & \multicolumn{2}{|c|}{ Lebar gerusan $(\mathrm{m})$} & \multirow{2}{*}{$\begin{array}{c}\text { Gerusan } \\
\text { terdalam (m) }\end{array}$} & \multirow{2}{*}{$\begin{array}{c}\text { No. Titik } \\
\text { Pengamatan } \\
\text { Gerusan terdalam }\end{array}$} \\
\hline & $\mathrm{L}_{1}$ & $\mathrm{~L}_{2}$ & $\mathrm{~B}_{1}$ & $\mathrm{~B}_{2}$ & & \\
\hline 5,37 & 0,20 & 0,20 & 1,00 & 1,00 & 1,28 & 1 \\
\hline 8,94 & 0,60 & 0,30 & 1,20 & 1,20 & 1,36 & 1 \\
\hline 12,52 & 0,80 & 0,40 & 1,20 & 1,20 & 1,48 & 1 \\
\hline 14,31 & 5,00 & 0,40 & 1,20 & 1,20 & 1,56 & 1 \\
\hline 17,89 & 6,50 & 0,40 & 1,20 & 1,20 & 1,64 & 1 \\
\hline
\end{tabular}

Sumber: Hasil Studi Balai Sungai (2014)

\section{Keterangan: Dimensi gerusan lokal}

$\mathrm{L}_{1}$ : panjang gerusan dari pilar ke hulu (m)

$\mathrm{L}_{2}$ : panjang gerusan dari pilar ke hilir $(\mathrm{m})$

$\mathrm{b}_{1}$ : lebar gerusan pada samping kiri (m)

$\mathrm{b}_{2}$ : lebar gerusan pada samping kanan $(\mathrm{m})$

Berdasarkan hasil analisis pengamatan pada Tabel 10, 11, dan 12, serta dimensi gerusan terdalam untuk ke tiga tipe pilar pada Tabel 13, diperoleh hasil bahwa tipe pilar tiang pancang menghasilkan gerusan terdangkal.

\section{Karakteristik Aliran di Model}

Karakteristik aliran menurut pengamatan di saluran jungkit pada saat awal sampai kondisi dasar saluran stabil adalah sebagai berikut:

Pada saat awal pengaliran sampai menit ke sepuluh dasar saluran berubah naik turun tidak beraturan, tetapi cenderung turun mendadak curam. Menit ke10 sampai menit ke 40, perubahan dasar saluran mulai stabil cenderung turun. Menit 40 sampai ke menit 105, perubahan dasar saluran mendekati stabil cenderung turun.

Menit 105 sampai ke menit 240, perubahan dasar saluran mulai stabil. Untuk mengetahui karakter aliran sub kritik/ super kritik dan turbulen/laminer perlu dianalisa dari data pengukuran di aliran saluran jungkit. Hasil analisis disajikan dalam Tabel 12.

Data yang dikumpulkan berasal dari hasil pengaliran di model fisik, yang dilakukan di Laboratorium Balai Sungai :

- Kedalaman air $(\mathrm{H})$ diukur langsung, dari saat perubahan dasar sampai muka air.

- Kecepatan aliran (V) diukur dengan pelampung 10 kali hasilnya dirata-ratakan.

- Temperatur air diukur rata-rata $20^{\circ} \mathrm{C}$, kekentalan kinematik air dari tabel $(\mathrm{V}): 1,01 \mathrm{X}$ $10^{-6} \mathrm{~m}^{2} / \mathrm{s}$

Dalam percobaan yang lain dengan prosedur yang sama, juga dilakukan pengaliran dengan melakukan perubahan dasar saluran (i) $=0,006$ dan $d_{m}: 0,60 \mathrm{~mm}$ dan $1,00 \mathrm{~mm}$ hasilnya disajikan dalam Tabel 13

Karakter gerusan lokal berdasarkan tipe pilar di simulasikan dengan debit aliran, kemiringan dasar sungai (i) 0,006 dan bahanmaterial dasar pasir halus disajikan dalam Gambar 5. 
Tabel 12 Karakteristik aliran Untuk Kemiringandasar saluran (i) : 0,006 dan dm : 0,60 mm =0,0006 m

\begin{tabular}{cccccccc}
\hline $\begin{array}{c}\text { Debit } \\
\left(\mathrm{m}^{3} / \mathrm{s}\right)\end{array}$ & $\begin{array}{c}\mathrm{B} \\
(\mathrm{m})\end{array}$ & $\begin{array}{c}\mathrm{h} \\
(\mathrm{m})\end{array}$ & $\begin{array}{c}\mathrm{V} \\
(\mathrm{m} / \mathrm{s})\end{array}$ & $\begin{array}{c}\mathrm{Dm} \\
(\mathrm{m})\end{array}$ & $\begin{array}{c}\mathrm{Fr} \\
\frac{\mathrm{V}}{\sqrt{\mathrm{gh}}}\end{array}$ & $\begin{array}{c}\mathrm{Re} \\
\mathrm{V}, \mathrm{dm} / \mathrm{v}\end{array}$ & Jenis aliran \\
\hline 1 & 2 & 3 & 4 & 5 & 6 & 7 & 8 \\
\hline 5,37 & 8,00 & 0,54 & 4,11 & 0,0006 & 1,73 & 540 & Super kritik/ Turbulen \\
8,94 & 8,00 & 0,70 & 4,15 & 0,0006 & 1,58 & 558 & Super kritik/ Turbulen \\
12,52 & 8,00 & 0,86 & 4,24 & 0,0006 & 1,47 & 570 & Super kritik/ Turbulen \\
14,31 & 8,00 & 0,94 & 4,38 & 0,0006 & 1,45 & 588 & Super kritik/ Turbulen \\
17,89 & 8,00 & 1,08 & 4,56 & 0,0006 & 1,40 & 612 & Super kritik/Turbulen \\
\hline
\end{tabular}

Keterangan: Kolom nomer 3 dan 4 hasil dari pengamatan di model

Tabel 13 Karakteristik aliran Untuk Kemiringandasar saluran (i) : 0,060 dan dm : 1,00 mm =0,001 m

\begin{tabular}{cccccccc}
\hline $\begin{array}{c}\text { Debit } \\
\left(\mathrm{m}^{3} / \mathrm{s}\right)\end{array}$ & $\begin{array}{c}\mathrm{B} \\
(\mathrm{m})\end{array}$ & $\begin{array}{c}\mathrm{h} \\
(\mathrm{m})\end{array}$ & $\begin{array}{c}\mathrm{V} \\
(\mathrm{m} / \mathrm{s})\end{array}$ & $\begin{array}{c}\mathrm{Dm} \\
(\mathrm{m})\end{array}$ & $\begin{array}{c}\mathrm{Fr} \\
\frac{\mathrm{V}}{\sqrt{\mathrm{gh}}}\end{array}$ & $\begin{array}{c}\mathrm{Re} \\
\mathrm{V}, \mathrm{dm} / \mathrm{v}\end{array}$ & Jenis aliran \\
\hline 1 & 2 & 3 & 4 & 5 & 6 & 7 & 8 \\
\hline 5,37 & 8,00 & 0,66 & 3,84 & 0,001 & 1,52 & 516 & Super kritik/ Turbulen \\
8,94 & 8,00 & 0,86 & 3,98 & 0,001 & 1,38 & 534 & Super kritik/ Turbulen \\
12,52 & 8,00 & 1,04 & 4,06 & 0,001 & 1,27 & 546 & Super kritik/ Turbulen \\
14,31 & 8,00 & 1,17 & 4,15 & 0,001 & 1,24 & 558 & Super kritik/ Turbulen \\
17,89 & 8,00 & 1,32 & 4,24 & 0,001 & 1,18 & 570 & Super kritik/ Turbulen \\
\hline
\end{tabular}

Keterangan: Kolom nomer 3 dan 4 hasil dari pengamatan di model

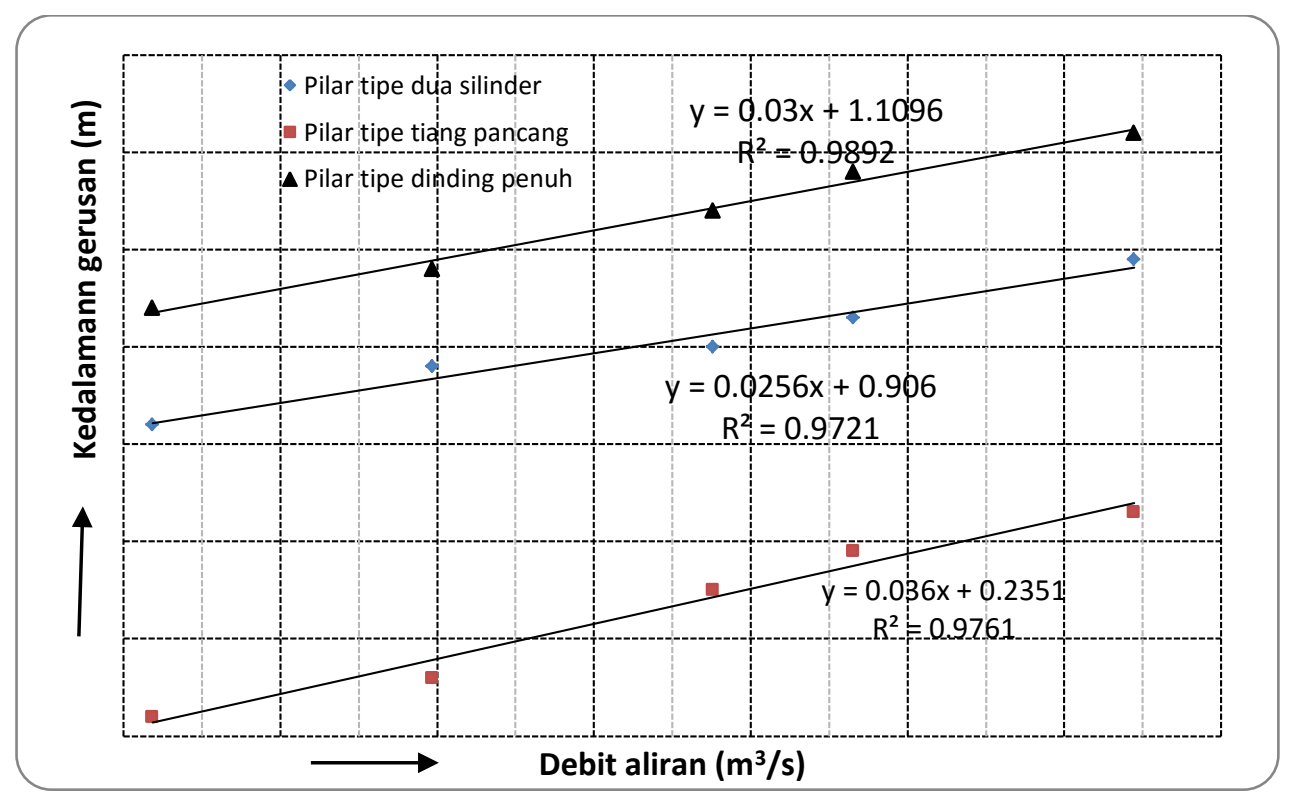

Gambar 5 Karakter gerusan lokal berdasarkan bentuk pilar 


\section{KESIMPULAN}

Penyelidikan gerusan lokal menggunakan 3 (tiga) tipe pilar jembatan dilakukan secara simultan. Hasil penyelidikan diperoleh jenis aliran super kritik (Fr > 1) dan turbulen (Re>500). Berdasarkan hasil studi, untuk gerusan lokal terdangkal pilar tipe tiang pancang, terdapat pada titik No. 2 atau pada pilar bagian samping. Untuk pilar tipe dinding penuh gerusan lokal terdalam adalah pada pilar bagian hulu atau pada pilar bagian ujung depan, dan untuk pilar tipe dua silinder gerusan lokal terdalam adalah pada titik pengamatan No.2 atau pada pilar bagian samping. Secara keseluruhan hasil studi diperoleh gerusan terdangkal pada pilar tipe tiang pancang, dan gerusan terdalam pada pilar tipe dinding penuh. Untuk pelaksanaan lapangan pemilihan tipe pilar supaya disesuaikan dengan kondisi di lapangan terutama dengan mempertimbangkan jenis angkutan sedimen yang ada.

\section{DAFTAR PUSTAKA}

Anwar, Y. 2004. Pengaruh Kecepatan Aliran terhadap Kedalaman Gerusan Lokal di Hilir Bed Protection. Skripsi Jurusan Teknik Sipil Universitas Negeri Semarang : Semarang.

S Aisyah, 2004, Pola Gerusan Lokal di Berbagai Tipe Pilar Akibat Adanya Variasi DebitTugas Akhir. Yogyakarta: UGM

Breuser, H,N,C, dan Raudkivi, A,J, 1991, Scouring Hidraulic Structure Design Manual IAHR, Balkema,
Chow Ven Te, 1985, Hidrolika Saluran Terbuka Penerbit Erlangga, Jakarta.

Garde, R,J and Raju K,G,R, 1997, Mechanics Of Sediment Transportation and Alluvial Stream Problem, New Delhi: Willy Limited,

Miller , W, 2003, Model For The Time Rate Of Local Sediment Scour At A Cylb Indrical Structure, Disertasi Florida : PPS Universitas Florida,

Pamularso, A, 2006, Pengaruh tipe pilar terhadap perilaku gerusan local, Skripsi, UNNES Semarang

Balai Sungai, 2014, Studi Gerusan Lokal dengan UMH Fisik, Laporan Akhir Kegiatan.

Sucipto dan Nur Qudus, 2004, Analisis Gerusan Lokal di Hilir Bed Protection.Jurnal Teknik Sipil dan Perencanaan. Nomer1 Volume 6.Januari 2004.Semarang : UNNES

Rita. M, 2010: Kajian gerusan lokal pada ambang dasar Akibat variasi q (debit), i (kemiringan) danT (waktu), Skripsi FT UNS

Triatmodjo, B., 1995, Hidraulika I. Jilid ke 3, Beta Offset, Yogyakarta.

\section{UCAPAN TERIMAKASIH}

Penulis mengucapkan terima kasih pada Dr. Ir. Istiarto, M. Eng, sebagai narasumber dan semua pihak yang telah membantu sampai selesainya tulisan ini. 